\title{
Almas em busca da salvação: sensibilidade barroca no discurso jesuítico (século XVII)
}

Eliane Cristina Deckmann Fleck ${ }^{1}$ Unisinos - São Leopoldo/RS

\section{RESUMO}

Para uma compreensão das reduções jesuítico-guaranis na perspectiva de uma história da sensibilidade, procedeu-se a uma releitura das Cartas Ânuas da Província Jesuítica do Paraguai, referentes ao período de 1609 a 1675 . O discurso jesuítico, especialmente através de suas falhas, permitiu reconhecer as reduções como espaço de reinvenção de significados, no qual se constrói uma sensibilidade religiosa própria, resultante da acomodação criativa da espiritualidade guarani e da devoção e piedade tridentinas.

Palavras-chave: Sensibilidade religiosa; Discurso jesuítico; Reduções jesuíticoguaranis.

\section{ABSTRACT}

An in-depth reading of the Cartas Ânuas of the Jesuit Province of Paraguay, concerning the period from 1609 to 1675 , was carried out to come to a deeper understanding of Jesuit-Guarani mission settlements within the framework of a history of sensibility. The Jesuit discourse, mostly through its gaps, allowed for the acknowledgement of the Mission Settlements as a space for the reinvention of meanings, in which it is possible to construct a unique religious sensibility that results from the creative accommodation of Guarani spirituality and of Tridentine devotion and piety.

Keywords: Religious sensibility; Jesuit discourse; Jesuit-guarani settlements. 
Sentir é algo ambíguo, pois o sensível é, ao mesmo tempo, a qualidade que está no objeto e o sentimento intenso que nosso corpo possui das qualidades sentidas ... na realidade, só temos sensações sob a forma de percepções, isto é, de sínteses de sensações. A percepção depende das coisas e de nosso corpo, depende do mundo e de nossos sentidos, depende do exterior e do interior.

Marilena Chauí

Uma excessiva formalização da vida pela sujeição a regras comportamentais caracterizou a Europa do início do período moderno, marcada pela percepção de que "por meio da conduta, dos costumes, das maneiras do vestuário, do porte" definia-se o grau de inserção na "verdadeira cultura".

Keith Thomas, referindo-se "à profunda modificação das sensibilidades" do homem moderno, aponta para a importância da moral e da religião, bem como da educação erudita para a civilidade e o refinamento que "tinham como objetivo elevar os homens acima dos animais ... Uma vez que todas as funções físicas tinham associações animais indesejáveis, alguns comentadores consideravam ser a moderação do corpo, ainda mais que a razão, o que distinguia os homens das bestas". Embora nem todos atingissem "um nível tão peculiar de autoconsciência ... a maioria das pessoas era ensinada a encarar seus impulsos físicos como impulsos 'animais', a exigir controle”. Comportamentos diversos dos estabelecidos eram considerados animalescos: "A luxúria, em particular, era sinônimo de condição animal, pois as conotações sexuais de termos como 'bruto', 'bestial' e 'animalesco' eram então muito mais fortes do que hoje ... A higiene física era necessária ... porque a sua falta, 'mais do que qualquer outra coisa, torna o homem bestial'. A nudez era bestial, pois as roupas, como o ato de cozinhar, constituíam um atributo humano exclusivo".

A interiorização de uma "moral da ordem e do controle" é também referida por Peter Burke como tendência do processo que denominou de "a reforma da cultura popular" ${ }^{4}$ que estabeleceria novos padrões morais que redefiniram a convivência social em termos de expressões de sensibilidade.

Para Norbert Elias, o final da Idade Média foi marcado por "uma tutela dos afetos, uma autodisciplina e um autocontrole", ${ }^{5}$ implicando uma "limitação de controle mais estrito da manifestação de emoções” ${ }^{6}$ e determinando "mudanças específicas na maneira como as pessoas se vêem obrigadas a conviver", decorrentes da "exigência de bom comportamento".

Refletindo sobre a influência dos setores dirigentes - "los sistemas de do- 
minación" - sobre a adoção de novas formas de sensibilidade, José Pedro Barran observa que "no se trata claro está ... de afirmar que la sensibilidad que mejor sirve los intereses dominantes en una sociedad sea la que sempre prevalece". 9

Também para Burke, a adoção das "formas da cultura oficial” não significou necessariamente a adoção dos "significados usuais associados a elas", ${ }^{10}$ na medida em que "os modos tradicionais de percepção e intelecção formam uma espécie de crivo que deixa passar algumas novidades e outras não". ${ }^{11}$

Mesmo considerando a possibilidade de opção entre assimilação ou resistência às novas formas de sensibilidade, hábitos e práticas como a violência e a licenciosidade sexual passaram a ser tidos como inadequados, reforçando a interiorização de padrões de nojo, de vergonha e de sentimento de culpa.

A “profunda modificação das sensibilidades” deve ser também entendida com base nas "condições de vida", nas "características da ambiência” dos séculos XVI e XVII, tais como a expectativa de vida, as condições físicas e de saúde da época, bem como a oferta de alimentos. ${ }^{12}$

Em seu estudo sobre as crenças populares da Inglaterra dos séculos XVI e XVII, Keith Thomas observa que a falta de higiene, o desconhecimento de anti-sépticos e a falta de um bom saneamento concorriam para os surtos periódicos de gripe, tifo, disenteria e varíola, refletindo não só a ignorância e a pobreza, mas também as condições de sujeira e amontoamento dos núcleos urbanos. $^{13}$

Havia, em razão disso, um profundo sentimento de impotência perante a doença e outros tipos de desgraça, restando aos sobreviventes implorar a misericórdia divina através da confissão, ${ }^{14}$ do jejum e das preces em intenção dos mortos. ${ }^{15}$

Em razão de seus reaparecimentos repetidos, as pestes criavam nas populações um estado de medo permanente, a que se somava o sentimento de culpabilidade ante a demonstração da cólera divina. ${ }^{16}$

Como bem salientou Bastos, "sob a ótica cristã, a doença fomentou a abordagem do pecado, da culpa, do arrependimento e da redenção", reforçando "as perturbações provocadas pela morte ... o traumatismo da morte" ${ }^{17} \mathrm{e}$ incentivando "a observância das leis que regulam o pacto entre Deus e os Homens". ${ }^{18}$

Prevalecia, portanto, a crença "de que existia uma íntima relação entre a conduta moral do homem e os aparentes caprichos de seu meio", ${ }^{19}$ do que de- 
corria a convicção de "que pouco se poderia esperar de remédios naturais, enquanto o paciente não se arrependesse de sua conduta”. ${ }^{20}$

Para o Cristianismo, "os apetites e desejos do corpo são encarados como cegos, obstinados, anárquicos ... Por isso, o corpo facilmente ofende, cometendo o mal ou atos pecaminosos/criminosos. Mas, em razão de sua verdadeira natureza (sendo Imperfeito, até bestial) ele pode, paradoxalmente, ser prontamente desculpado" pela fraqueza da carne. A mente, no entanto, “é obrigada a ascender acima de tal desordem; se implicada, a vontade, idealmente livre e nobre, parece ainda mais culpada de ofensa". A questão de como, precisamente, "atribuir honra e vergonha, deveres e responsabilidades respectivamente à mente e ao corpo tem sido crucial para a avaliação do homem como um ser racional e moral". ${ }^{21}$

Assim, é possível constatar que o que se propunha efetivamente era uma nova atitude religiosa, moralizante, em decorrência "da preocupação com o grande desregramento dos costumes ou a 'deterioração espiritual' que se reforça na cultura renascentista". 22

Segundo Huizinga, "em nenhuma outra época como na do declínio da Idade Média se atribuiu tanto valor ao pensamento da morte", ${ }^{23}$ assim "as mais cruas concepções da morte, e somente essas, se fixavam continuamente nos espíritos ... o pensamento dominante ... quase mais nada conheceu relativamente à morte do que estes dois extremos: a lamentação acerca da brevidade das glórias terrenas e o júbilo pela salvação da alma". ${ }^{4}$

José Pedro Barran lembra que é preciso que "reconozcamos, en primer lugar, que la Iglesia aparece como la gran enemiga de la muerte repentina por sus probables efectos condenatorios para el alma del enfermo - y que por ello pudo haber influido en una población que creía en los castigos del infierno y el purgatorio". 25

Os principais artífices da vinculação das epidemias aos castigos divinos foram os clérigos que a "instrumentalizaram, instituindo e disseminando esta concepção através de discursos orais e escritos, imagens, ritos e cerimônias..." ${ }^{26}$ e estabelecendo que as curas se davam através da "intervenção da medicina de Deus". ${ }^{27}$

É importante lembrar que "também era inevitável que, em torno da igreja, o clero e todo o seu aparato sagrado congregassem uma infinidade de superstições populares, que conferiam aos objetos religiosos o poder mágico que os próprios teólogos nunca haviam reivindicado".28 29

Esse aspecto pode ser observado tanto no emprego da água benta e das relíquias sagradas e no culto dos Santos, quanto na manutenção de algumas 
convenções relativas ao enterramento dos mortos, tais como a de que o corpo deveria ficar voltado para o nascente e que o funeral deveria incluir óbolos para os pobres, o que estava evidentemente associado à preocupação com o bem-estar espiritual da alma do falecido.

Com relação à administração dos sacramentos, vale lembrar que a extrema-unção era recebida pelos moribundos, ocasião em que eram ungidos com o óleo santo e recebiam o viático. A recepção deste último estava envolta em uma série de superstições, dentre as quais se destaca a de que se constituía em, praticamente, uma sentença de morte.

O Concílio de Trento, posteriormente, procurou refrear esse temor em relação à recepção do viático, vinculando-a à unção dos enfermos e revestido-a de um caráter de auxílio na recuperação do paciente. De qualquer forma, o "terror da morte de que os sacerdotes se servem" produziu a introjeção de valores piedosos, da qual resultava uma conduta social renovada pelos preceitos morais da religião. Difundia-se a crença de que somente os justos, purgados e educados se encontrariam com o Senhor no Paraíso.

Na percepção de Bastos, a Igreja "purificou o simbolismo tradicional", porque "converteram-se símbolos sem destituí-los do significado original que lhes conferia a simplicidade humana", com a intenção de "orientar, controlar a ingerência do sobrenatural na ordem terrena". ${ }^{30}$

Constata-se que a Igreja aceitou a permanência desses ritos anteriores ao Cristianismo, limitando-se a condenar as práticas que tentavam fugir à sua vigilância, mercê da consciência que tiveram os homens da Igreja quanto à estreita relação existente entre medo e religião e da necessidade de preservação dos rituais que empregavam o exorcismo. ${ }^{31}$

Há que considerar que, apesar de traçarem uma nítida linha divisória entre religião e superstição, os teólogos mantiveram uma elasticidade em relação ao conceito de superstição, preservando estes, no entanto, a prerrogativa no seu enquadramento e classificação.

Era supersticioso usar objetos consagrados para finalidades outras que não as originais.... tentar obter resultados além dos que pudessem ter causas naturais, por qualquer procedimento que não tivesse sido autorizado pela Igreja ... não era supersticioso acreditar que os elementos podiam alterar suas naturezas, depois de pronunciadas sobre eles as fórmulas de consagração: isso não era magia, e sim uma operação efetuada por Deus e pela Igreja, ao passo que a magia supunha o auxílio do Demônio. ${ }^{32}$ 
A Igreja reforçava ainda mais a crença popular nos seus poderes mágicos, na medida em que colocava à disposição a contramagia, isto é, armas espirituais, rituais controlados pela Igreja para afastar as investidas do Demônio. ${ }^{33} \mathrm{Na}$ medida em que esses rituais conferiam consolo frente aos problemas cotidianos, a Igreja não pôde ignorá-los, tendo que reconhecer sua importância, já que "se de qualquer forma o povo ia recorrer à mágica, seria muito melhor que fosse uma magia sobre a qual a Igreja tivesse algum controle”. ${ }^{34}$

Além da pregação e da exortação, a confissão constituía, potencialmente, "um sistema de disciplina pessoal", ressaltando seu caráter de coação existente na confissão obrigatória, já que "era preciso pedir e obter perdão". ${ }^{35}$

Para os cristãos dos séculos XVI e XVII, a "vida é apresentada ... já não como o objeto de um julgamento, mas como a última oportunidade de provar a sua fé". ${ }^{36}$ Em decorrência disso, a tradição cristã estabeleceu que a morte era uma espécie de sono profundo, mediado pela expectativa da ressurreição, quando as almas voltariam a habitar os corpos. Essa idéia introduziu uma nova percepção e poupou gerações, ao longo de séculos, da idéia aterradora do fim definitivo.

As aparições das almas do Purgatório que vinham pedir aos vivos orações, coletas de donativos ou reparação de erros cometidos foram transformadas em uma crença de significação moral pela Igreja. ${ }^{37}$ Isso implicou uma nova atitude cristã a respeito dos mortos, na medida em que estes deixaram de fazer medo aos vivos e que se ampliava o apego ao dogma da ressurreição dos corpos.

A ressurreição, por sua vez, esteve ligada até o século XIV a uma concepção judiciária do mundo, a do Juízo Final, na qual o moribundo se via diante de uma audiência solene, na presença de todas as forças do Céu e do Inferno, cabendo a ele vencer as seduções dos diabos com o auxílio do seu anjo da guarda. ${ }^{38}$

A evocação dos horrores da decomposição durante a vida, tanto como depois da morte, explorada por literatos, pintores e clérigos, produziu entre os ainda não-cristãos uma prontidão para a aceitação da vida eterna e da separação total da alma e do corpo.

Considerando a evolução das percepções da doença e da morte, e seus desdobramentos em termos de sensibilidade religiosa, na América, deve-se ressaltar que "la situación en el Nuevo Mundo no parece que alterara sustancialmente el campo de las devociones de los españoles que se asentaron allí”, pois, "los españoles en Indias llevaron consigo sus manifestaciones habituales de piedad" ${ }^{9}$

É importante reconhecer também que "al igual que en Mesoamérica, la 
religión del siglo XVI en Castilla era un asunto colectivo que incluía la propiciación de una hueste de seres sobrenaturales que poseían una serie de atributos tanto benévolos como malévolos". 40

$\mathrm{Na}$ Castela do século XVI, a religião cristã se achava mesclada com uma grande dose de magia, o que pode ser observado no fato de que "nigromantes, ensalmadores y conjuradores de nubes competían a menudo directamente con los párrocos", ${ }^{41}$ que recorriam a um arsenal de orações e exorcismos aprovados pela Igreja. ${ }^{42}$

A utilização da "magia popular" era recomendada sempre e quando "no implicara la invocación demoníaca o la transferencia de enfermedades”, ou quando os remédios como a água benta, o sinal da cruz e as ervas consagradas haviam fracassado. ${ }^{43}$

Às religiões indígenas mesoamericanas foram atribuídos qualificativos determinados a partir de suas práticas rituais nas quais se destacavam, na expressão dos missionários, a "contaminación satánica y la inmundicia ritual", o que favoreceu a associação com o demonismo, tão em voga no século XVI. ${ }^{44}$

Por se considerarem portadores da mensagem evangélica, enviados "a fin de iluminar a los que habitan en tinieblas y sombras de muerte”, ${ }^{45}$ os missionários procuraram, em seus sermões, pregar sobre a libertação do poder do demônio e do pecado. A figura do demônio, contudo, não pode ser reduzida a um mero instrumento de conveniência religiosa e política - em se tratando da conquista política e, também, espiritual — , devendo-se considerar "la sincera creencia de la mayoría de los contemporáneos en la autenticidad del demonismo". ${ }^{46}$

Esses conceitos aplicados ao mal e ao demônio "no formaban parte del bagaje intelectual mesoamericano", porque "los conceptos mesoamericanos del mal y de lo demoníaco estaban inextricablemente ligados a sus conceptos del bien y de lo divino. El mal y lo demoníaco, de hecho, eran intrínsecos a la misma divinidad". ${ }^{47}$

Foi em face da necessidade de definição de novos conceitos de evangelização e missão que o Papa Paulo III emitiu, em 1540, a Bula "Regimini Militantis Ecclesiae", criando a Companhia de Jesus, que ficava obrigada "quando estiver na nossa mão, a ir sem demora para qualquer região aonde nos quiserem mandar...”. ${ }^{48}$

O fundador da Companhia de Jesus, Inácio de Loyola, acreditava que para alcançar a salvação da alma "o chamamento de Cristo Rei, que ... convoca ao combate contra as potências de Satanás, sob o estandarte da Cruz", deveria ser aceito. ${ }^{49}$ 
Nesse sentido, a expressão "Deus quer" dos jesuítas parece evocar a "cruzada" que os missionários pretendiam empreender contra os exércitos de Satanás e os sinais flagrantes de sua obra na América. ${ }^{50}$

Também a Companhia de Jesus integrou-se ao esforço de modificação de condutas morais e sensibilidades. Na fórmula do Instituto da Companhia de Jesus, de 27 de setembro de 1540, o próprio Inácio de Loyola determinava "que o homem é levado a poder vencer-se a si mesmo e assegurar sua forma de vida por uma determinação livre de aflicções prejudiciais ... [pela educação do corpo e do espírito] pois o que sustenta a fé é a educação das gerações em suas virtudes". A educação do corpo era, portanto, um meio de educar a alma. E, mesmo as representações do corpo humano deveriam ser cuidadosamente elaboradas. Pois, a partir desse pressuposto, a exposição dos corpos não somente era inadmissível, do ponto de vista moral, como também era inadequada à civilização do espírito.

Deve-se ressaltar também que pela lógica aristotélica, parte importante da construção argumentativa do humanismo jesuítico, o pensamento é corpóreo, há a união entre o corpo e a alma, logo a ação do corpo e as sensações físicas estão em relação com os movimentos da alma. Porém, esta é uma relação de opostos, já que o corpo se degenera, mas a alma pode evoluir. Restringir o uso do corpo em detrimento do uso dos sentidos que fizessem evoluir a alma significava ordenar esses movimentos a fim de atingir a ação racional do corpo.

Em 1601, o Superior Geral da Companhia de Jesus decidiu reunir as regiões do Rio da Prata, Tucumã e Chile numa Província independente, com o nome de "Paraguay", ${ }^{51}$ para a qual foram definidas diretrizes em 1609 e 1610. O $1^{\circ}$ Concílio do Rio da Prata, realizado em Assunção, em 1603, tem, nesse contexto, uma importância fundamental, por estabelecer as metas a serem alcançadas pelos missionários, as orientações e os meios a serem empregados para "la enseñanza de la doctrina a los indios y la reforma de costumbres de los españoles". ${ }^{52}$

As determinações resultantes desse Concílio tornaram-se, portanto, um referencial para o trabalho missionário, refletindo-se nas duas Instruções do Pe. Diego de Torres Bollo (1609 e 1610) (53 $^{3}$ aos missionários que atuavam junto aos Guarani no Paraguai.

Registramos aqui algumas das Constituições aprovadas pelo Concílio e que revelam os princípios que nortearam a ação dos missionários jesuítas, em especial, em relação aos procedimentos a serem adotados com os doentes e moribundos, importantes para nosso estudo: 
6 ${ }^{\text {a }}$ Constitución. Que se quiten las borracheras y supersticiones de los indios.

... y particularmente tengan de quitar los llantos y ritos supersticiosos que tienen en las muertes de los indios. ${ }^{54}$

É interessante observar, com referência a esta orientação, a opção pela eliminação dos rituais fúnebres e das manifestações de exteriorização de sentimentos que os acompanhavam, por serem incompreendidas e identificadas com superstições e gestos bárbaros que atentavam contra a própria vida.

A referência ao Viático, na $7^{\underline{a}}$ Constituição, deixa claras as condições de sua administração e ressalta sua vinculação com a salvação da alma ("el bien que reçiuen"):

\section{$7^{\text {a }}$ Constitución.}

... y, así Ordenamos y mandamos que se dé el viático a los indios dispuestos para reciuirlo, y los dispongan para este efecto sus curas y pastores, pues en tiempo de tanta necesidad han menester grandemente tan grande socorro y ayuda y asimismo se les dé a todos los adultos la extremaunçión en el artículo de la muerte, en tiempo en que sepan el bien que reçiuen... ${ }^{55}$

9ํㅡㄹ Constitución.

Que todos los curas confiesen a los enfermos, y los señores de los indios los llamen. ... y, cierto, debería al principio de cualquier enfermedad hacerlo, pues por el poco regalo que estos indios tienen, en pequeña enfermedad se mueren... ${ }^{56}$

$13^{\mathrm{a}}$ Constitución.

... que los médicos y cirujanos luego al prinçipio de la enfermedad, hagan que se confiesen los enfermos, solas penas en ellos contenidas. ${ }^{57}$

Estas Constituições prevêem que os enfermos sejam assistidos com a confissão dos pecados e acrescentam que, dadas as condições existentes - "no hay médicos, ni medicinas" ${ }^{58}$ - e aos efeitos desastrosos das epidemias, os indígenas enfermos deveriam se confessar para obterem a absolvição e a garantia da salvação.

De qualquer modo, o uso da expressão "pequeña enfermedad" nos parece inadequado, devendo-se talvez ao desconhecimento ou a informações distorcidas, quanto às condições de saúde dos indígenas que os missionários recebiam das autoridades civis e dos colonos espanhóis.

Considerando o ano de sua aprovação e as experiências de missão/evangelização anteriores, pode-se atribuir a obrigatoriedade da confissão à tenta- 
tiva de sua universalização, para evitar mortes sem arrependimento e absolvição, decorrentes do retardamento do sacramento.

As duas Instruções do Pe. Diego de Torres Bollo renovam as metas estabelecidas em 1603 e reforçam determinadas orientações quanto à metodologia a ser empregada pelos missionários, enfatizando a necessidade de "tirarlhes os pecados públicos e pô-los sob policiamento", bem como de afastar os feiticeiros, por serem muito perniciosos e incitarem os índios a permanecerem em suas superstições. ${ }^{59}$

Para a finalidade deste estudo, selecionamos alguns artigos da $1^{\underline{a}}$ Instrução, na qual o segundo artigo que refere os cuidados que os missionários deveriam ter com a sua própria saúde, ressaltando que eles deveriam acreditar na justiça e bondade divinas e confiar na proteção dos santos e dos anjos:

$2^{\circ}$ artigo: Cuidarão Vossas Reverências de sua saúde e cada um pela de seu companheiro; e guardarão a devida prudência nos jejuns, vigílias e penitências, bem como em abraçar e acometer os perigos, sem faltar contudo em que for necessário na confiança que devem ter na Bondade divina e paternal Providência, e na intercessão da Soberana Virgem e dos Anjos da Guarda... ${ }^{60}$

O terceiro artigo refere-se à construção de igrejas e a sua condição de espaço sagrado, e ressalta o emprego das relíquias na liturgia e na vida piedosa do Catolicismo: ${ }^{61}$

3ำ artigo: Em todas as igrejas que passarem a edificar ... coloquem uma relíquia com a melhor decência possivel, ficando ela ali para ser levada aos enfermos. E ponham no altar principal imagens de nossos Beatos Padres Inácio e Xavier, embora sejam de estampas, tendo-se também alguma para os doentes. ${ }^{62}$

Ainda nessa $1^{\underline{a}}$ Instrução, destacamos o nono artigo, pela referência que faz aos procedimentos terapêuticos e espirituais adotados em relação aos enfermos:

9ำ artigo: No tocante a doutrinar os indios, a tirar-lhes os pecados públicos e pôlos em policiamento, terão de ir muito pouco a pouco, até tê-los ganho muito para si. Nisto e nem no sustento de Vossas Reverências não lhes sejam de qualquer peso ou carga. Mas, ao entrar, batizem as criaturas enfermas e catequizem os adultos doentes, de maneira que nem grande nem pequeno morra sem batismo. Isto não somente em sua aprovação, mas em toda a redondeza, tendo-se recomendado aos 
indios da comarca que avisem quando eles, ou seus filhos e parentes, estiverem enfermos. E o espanhol que for com Vossas Reverências cure-os a todos, sangre-os e os purgue, e faça com que o ajudem, bem como lhes dê os poucos presentes que houver e vá ensinando a algum índio para a mesma finalidade. ${ }^{63}$

É importante observar que apesar de os jesuítas terem se dedicado ao alívio dos doentes e ao estudo da Medicina, "parece que no les favorecía en esta materia, ni el Derecho Canónico, ni las Constituciones de la Orden, pues, hablan estas de las ocupaciones que no convienen a clérigos y religiosos y entre ellas se cuenta la medicina, y mucho más el comercio al parecer intimamente ligado al sosten de boticas". ${ }^{64}$

Essas proibições podiam ser, no entanto, desconsideradas, quando o atendimento se fazia necessário, "tratandose de la misericórdia y caridad para con los pobres, cuando hace falta otro médico o cirujano", ${ }^{65}$ prática que levaria o Papa Gregório XIII, em 1576, a outorgar à Companhia de Jesus permissão para a prática da medicina, nos seguintes termos:

Ya que consta por la experiencia, que los fieles se inclinan mucho a la religión y piedad, si las personas religiosas ejercen para con ellos los oficios de la caridad, no sólo con sus almas, sino también con sus cuerpos, y habiendo la Compañía de Jesús, según supimos, algunos religiosos entendidos en medicina, cuya asistencia ante todo en regiones donde faltan médicos, puede ser muy útil no sólo para las almas, sino también para los cuerpos, contribuyendo este oficio de caridad no poco a la edificación y a la gloria de Dios: para habilitar a semejantes religiosos a esta práctica, sin que incurran en censuras, ni se inquieten en su conciencia ... damos este presente indulto con autoridad apostólica ... a todos y a cada uno de la referida Compañía de Jesús, entendidos en medicina, que hay ahora o que hubiere en adelante, para que, con el permiso de sus superiores libre y lícitamente curen ... tanto a los enfermos de la misma Religión, como a extraños y seglares con tal que no se trate de adistión o incisión hecha por ellos en persona; y en el caso de que no pueda comodamente acudir a los médicos seglares... ${ }^{66}$

Durante os séculos XVI e XVII e, ainda na primeira metade do século XVIII, os jesuítas puderam exercer a medicina " $y$ expender a la gente las necesarias medicinas", face à não existência dos chamados "Protomedicatos" implantados nos diversos Vice-Reinos somente após a primeira metade do século XVIII. A referida falta de médicos é atestada pela solicitação, feita em 1642, pelo Cabildo de Buenos Aires à cidade de Córdoba, na qual fica expres- 
so que diante de "los frecuentes apuros de peste" se faz necessária a vinda de um médico, já que "no hay médico ni medicinas". ${ }^{67}$

Cabe aqui referir o sétimo artigo da $1^{\underline{a}}$ Instrução, que deixa claras as condições que deveriam ser observadas pelos jesuítas no momento da instalação da redução e que estão associadas à preocupação com o controle de doenças e com o eficiente abastecimento de alimentos. Nesse sentido, além de atuarem como médicos nas situações de epidemias, procuravam, através de medidas de prevenção, evitar a debilitação dos indígenas pela fome ou pela instalação de determinadas enfermidades.

$7^{\circ}$ artigo: No sítio mais apto façam a Redução e a povoação ... Nisso advertirão primeiro que tenha água, pescaria, boas terras e que estas não sejam todas alagadiças, nem muito quentes, mas que tenham bom clima e se apresentem sem mosquitos e isentas de outros incômodos... ${ }^{68}$

Ainda na $1^{\underline{a}}$ Instrução, recomendou-se que:

10ํaㅁigo: Aos índios já cristãos hão de dar a extrema-unção (unção dos enfermos) a seu tempo, depois de lhes haver explicado a virtude deste Sacramento, administrando-o, bem como os demais (Sacramentos), sempre com toda a decência e solenidade. Em particular valha isso dos Batismos, máxime dos primeiros a fazer, em que se há de juntar a principal gente adulta e bem catequizada. Faça-se o mesmo nos enterros, levando-se grinaldas para as criaturas inocentes. E procurem despertar toda a reverência às coisas sagradas, como à água benta, aplicando-a aos enfermos e ordenando que a tenham em decência em suas casas, e com ela crucifixos em todas, especialmente nas dos cristãos. Diante deles somente se diga a missa, não consentindo, sem causa grave, que a ela assistam os infiéis. ${ }^{69}$

$11^{\circ}$ artigo: ... Sejam os sermões tais que se lhes declare algum mistério, artigo ou mandamento, repetindo-o muitas vezes e usando de comparações e exemplos. ${ }^{70}$

$\mathrm{Na} 2^{\underline{a}}$ Instrução, encontramos os procedimentos a serem adotados pelos missionários em situações de doença e de morte:

9ำ artigo: Na Igreja e no cemitério se pregue sobre algum mandamento com muitas repetições. Aos domingos haja sermão na igreja. ${ }^{71}$

$10^{\circ}$ artigo: Sabendo-se que algum infiel se encontra doente, vá-se com todo o cui- 
dado catequizá-lo e oferecer-lhe algum presente. Aos que morrerem cristãos, enterrem-nos com a solenidade possível, não consentindo nisso e nem em outra coisa qualquer superstição. ${ }^{72}$

$11^{\circ}$ artigo: Toque-se o sino três vezes por dia para a oração e, à noite, em lembrança das almas dos defuntos. E saiam então dois rapazes pelo povoado para exortarem que as encomendem a Deus. ${ }^{73}$

13ำ artigo: Pela administração de sacramentos e para fazer enterros por ora não se peça nada de forma nenhuma. ${ }^{74}$

Antes que isso, diga cada padre semanalmente uma missa pelos índios e, morrendo algum deles, também se celebre uma missa por sua alma. ${ }^{75}$

Dada a insistente recomendação de que missas deveriam ser oficiadas pelos missionários nas situações aqui referidas, pode-se avaliar as razões que motivaram a resistência ao ritual do enterro cristão nos primeiros tempos das reduções jesuítico-guaranis, uma vez que os indígenas o perceberam como aprisionamento da alma do defunto. Esse comportamento pode ser observado em outros povos primitivos, para os quais "aquele que não é enterrado segundo o costume não está morto. Além disso, a morte de uma pessoa só é reconhecida como válida depois da realização das cerimônias funerárias, ou quando a alma do defunto foi ritualmente conduzida à sua última morada...".76

De outro lado, os missionários também reagiram às práticas de enterramento indígena, como se observa no registro do padre Montoya, em Carta Ânua de 1628, no qual informa como os Guarani enterravam seus mortos, fazendo também as suas considerações críticas acerca daquilo que considerou "ignorançias y abusos":

entierran sus difuntos en el campo haciendo sobre la sepultura una chocuella y de cuando en cuando van a limpiar la yerba que naçe en ella porque asi dicen que descansa el difunto, otros, lo entierran en casa por tenerlos en su compañía, al tiempo de enterrar el difunto cortan los puños de las hámacas en que los entierran porque si no se moriran otros de la misma casa, y por la misma raçon quitan las cuerdas de la hamaca, y en la sepultura mientras lo entierran no a de caer basura alguna porque si cae se morian otros de aquella parcialidad. Si la defunta es India que tenia hijo al pecho va una vieja a la sepultura con un redaço [?] y como que ensaca con el algo lo mece dos o tres veces con lo qual sacan el alma de alli porque el niño no se muera porque el alma de la India ayuada a criar 
al niño y se se queda en la sepultura el niño a de morir. Si despues de enterrado el difunto se oyen algunos trueños lejos dicen que son unas fantasmas, que se sustentan de cuerpos muertos y que entonces se juntan, para comer aquel.

Todas estas son ignorançias, y abusos que facilmente se quitan avisandoles y asi en los pueblos que an tenido doctrina no se halla cosa destas o mui poca lo qual todo van dejando con el santo batizmo que reciben... ${ }^{77}$

O mesmo Pe. Montoya registrou em 1639 — já decorridos trinta anos desde o início do processo reducional — a sobrevivência da crença nos feiticeiros "enterradores":

Os piores e mais perniciosos vêm a ser os "enterradores" cujo ofício é matar, enterrando eles na casa de quem se deseja matar, algumas sobras de sua comida, cascas de fruta e pedaços de carvão etc. Às vezes enterram sapos atravessados com alguma espinha de peixe: com o que se vai enfraquecendo aquele que querem matar, e este, sem outro acidente, morre. ${ }^{78}$

A compreensão de que as funções de sacerdote e de médico eram necessariamente complementares muito favoreceu os missionários, na medida em que conscientes dos efeitos da manipulação da cura e da não-cura buscavam a adoção pelos indígenas de novas condutas em substituição das denominadas "abomináveis".

Os registros condenatórios das práticas terapêuticas xamanísticas enfatizam sua inadequação e, sobretudo, seu caráter demoníaco e supersticioso. Foram, sem dúvida, a mística envolvida nas curas e os rituais mágicos que garantiam sua eficácia que causaram a oposição dos missionários. Daí ser possível perceber o confronto entre xamãs e missionários, como uma disputa de saberes e poderes, pelo controle das doenças e pela manipulação das curas e não-curas. Na medida em que não propriamente os recursos medicinais sofreram contestação, os registros feitos pelos missionários, ao longo do século XVII, revelam uma absorção cada vez maior da farmacopéia, bem como da terapêutica indígena. Isto não só ampliou as possibilidades de manipulação das curas, como reduziu significativamente a avaliação depreciativa decorrente da afirmação de que os Guarani "no tienen medicinas”.

As Cartas Ânuas da Província Jesuítica do Paraguai que analisamos registram, em razão disso, a percepção dos missionários, para quem pestes e epidemias resultavam da cólera divina, como nas passagens que aqui destacamos: 
con estas cosas pareze q. suficientemte nos habia ayudado el Señor dandonos a entender, que queria el mirar por este pueblo, pero aun mas claramente nos $l o$ ha manifestado castigando a otros. ${ }^{79}$

Aquí no hizo menos estragos la peste, que en otras partes.

$\mathrm{Al}$ oir los indios de los Padres, que semejantes epidemias son instrumentos de la divina justicia, se fueron a ellos rogándoles que organizasen solemnes rogativas para aplacar la ira de Dios... ${ }^{80}$

Apesar de serem apresentadas como "instrumentos de la divina justicia", as epidemias, quando isoladas ou controladas, passaram a ser percebidas como sinais da proteção divina, em função dos resultados obtidos através delas.

São numerosos os relatos em que os missionários registram os efeitos que essas intervenções divinas através das pestes (doenças, em geral) ou das curas milagrosas produziam sobre a conduta moral dos indígenas. As pestes, os períodos de fome ocupam de forma significativa os relatos de 30 e 50, na medida em que passaram a ser as razões potenciais dos fracassos da ação missionária entre os Guarani. Esse é o período que oferece para a análise do discurso jesuítico os relatos mais ricos em relação às curas, aos sonhos, às visões e às "mortes aparentes" descritas pelos missionários envolvidos numa atmosfera de intensa exaltação emocional.

Eles ilustram, sobretudo, a ênfase dada no discurso missionário jesuítico à relação que se estabeleceu entre o medo da doença e da morte, a conversão ao Cristianismo e a adoção de novos padrões de comportamento e de sensibilidade, expressos nas manifestações de devoção. Deve-se ressaltar que reside aí a maior alteração em relação à percepção da morte, entre os Guarani reduzidos, uma vez que o medo da morte, que não integrava sua vivência religiosa, foi introduzido pela conversão ao Cristianismo. ${ }^{81}$

Significativas para a análise dessa relação e de seus desdobramentos, não só em termos de representações, mas também em termos de práticas sociais, são estas passagens extraídas das Cartas Ânuas referentes ao período de 16101613 (fase inicial da implantação do modelo reducional) e que registram o medo de morrer infiel e de ir para o inferno em razão disso. Chamo a atenção para expressões que ressaltam a prontidão com que os indígenas manifestavam a intenção de ser batizados para "que no muriesen como bestias", a exteriorização da nova fé através da devoção e fervor públicos e, ainda, os efeitos sobre os mais resistentes que se refugiavam nos montes, apegados ao seu "antigo modo de ser".

Em vários relatos de batismo a moribundos encontramos a associação 
entre os sacramentos do batismo e da confissão, imagens como céu e inferno, que revelam o universo simbólico jesuítico e o processo de produção e difusão de representações nas reduções. Deve-se considerar que não se trata de uma simples transposição de representações, mas que esses relatos indicam a "construção" de representações sociais num novo contexto, o reducional, por novos agentes sociais, os índios Guarani. Esse processo, no qual os missionários manejaram símbolos e valores, definindo sua direção e assimilação, foi, no entanto, condicionado às motivações e às aspirações dos indígenas.

Considerando que os registros das Cartas Ânuas referem "mudanças de vida", é oportuna a lembrança das reflexões de Norbert Elias em relação à "civilização da conduta", através do controle de paixões e sentimentos, motivado por razões de ordem social, ${ }^{82}$ bem como do medo da transgressão de proibições sociais, implicando conseqüências desagradáveis. ${ }^{83}$

Outro aspecto que merece destaque no discurso jesuítico sobre as pestes é o que se refere à preocupação que os missionários têm em também encontrar as causas naturais (aqui prevalecendo o caráter prático e não o sobrenatural) das constantes enfermidades que se abatem sobre as reduções. Cabe observar que "o maravilhoso, urdido pelo sobrenatural, inexplicável para sempre” vinha definindo a percepção dos missionários jesuítas, na medida em que assegurava o ordenamento e o controle das práticas sociais nas reduções jesuítico-guaranis. A preocupação com as causas naturais das doenças pode ser atribuída à consciência com relação à importância "do bom estado da agricultura” e da ausência dos fatores predisponentes às doenças, para o sucesso do projeto reducional. Pode-se, ainda, atribuí-la à grande importância de transgressões e ao retorno às práticas antigas, revelando a fragilidade do apelo exclusivamente ao maravilhoso/sobrenatural; o que teria forçado os missionários a uma conciliação entre o sobrenatural e o natural e a uma atuação que poderia se denominar preventiva. Em várias Cartas Ânuas encontramos referências a pragas de ratos, a períodos longos de fome, a calamidades climáticas que implicavam a perda da colheita e aos ataques dos bandeirantes paulistas como causas de doenças e do retorno aos montes (evasão das reduções) e ao antigo modo de ser, para desespero dos missionários. ${ }^{84}$

Há ainda uma preocupação em registrar de forma bastante detalhada o processo das doenças (o contágio, as tentativas de cura - empíricas ou exorcistas - ou então a morte), bem como registrar as principais enfermidades (gripe, disenteria, lepra, sarampo, tifo, varíola) que se abatiam sobre os indígenas reduzidos e os colonos espanhóis instalados nos "pueblos".

Esses registros revelam não só a preocupação com o detalhamento da 
evolução das doenças, mas também a percepção ocidental da doença através das imagens que constroem um "retrato de la muerte", bem como através da sua possível vinculação ao demônio.

As descrições feitas pelos missionários exploram amplamente as sensações de dor, compaixão e repugnância, através do forte apelo aos sentidos do olfato e da visão, levando-nos a refletir sobre o impacto que a evolução das doenças introduzidas pelos europeus causaram nos indígenas, traumatizando-os e predispondo-os a buscar a salvação da alma na conversão ao Cristianismo. ${ }^{85}$

Cabe observar que em alguns registros os padres admitem que as doenças não decorrem, exclusivamente, da "divina justicia", mas que "a consecuencia de la transmigración y el cambio de clima aparecieron frecuentes dolencias en el pueblo", oportunidade para "experimentalismo", como na referência a que "aplicaron las medicinas del campo de aquella región, pero sin ningún resultado", e ainda para recrutar enfermeiros entre os índios sãos, "para investigar si los había [enfermos] en las casas, campos y selvas" e vigiar "contra la antigua superstición de los hechiceros". ${ }^{86}$ Esse racionalismo e experimentalismo, no entanto, não impediu que fossem expressivos os relatos de curas milagrosas através de práticas mágicas, registradas nas Cartas Ânuas.

Considerando que os missionários, a despeito de suas convicções religiosas (e de seu universo simbólico), desenvolveram um agudo senso de observação em relação às condições propiciadoras das doenças, torna-se bastante provocativa e passível de uma releitura a passagem registrada na Carta Ânua referente ao ano de 1616: "también con los pocos remedios que aca ay procuramos curarlos por que ellos no tienen medicinas ni hacen remedios sino dexassen morir" ${ }^{87}$

O aspecto que mais nos chama atenção é que esse registro é anterior à obra de Montoya (Conquista Espiritual, 1639) e caracteriza-se pela não referência às práticas de caráter preventivo e terapêutico, nem às de caráter mágico-ritual, difundidas entre os Guarani, mencionadas com detalhamento por Antônio Ruiz de Montoya.

Cabem estas indagações: por que a referência aos poucos remédios e ao fato de que "no tienen medicinas, ni hacen remedios"? O que teria levado os indígenas a se deixarem morrer?

E as possíveis respostas: a ausência de referências às práticas curativas indígenas dever-se-ia à incompreensão, conseqüência do total desinteresse/desconhecimento sobre as línguas e os sistemas culturais descritos; também ao te- 
mor de registrar práticas heréticas; dever-se-ia, ainda, à redução à feitiçaria das práticas curativas, considerando que não eram aprovadas pelos missionários.

Poderíamos ainda levantar os seguintes questionamentos:

- O relato destacado pode ser tomado como um documento que reflete uma total conversão e assimilação aos modelos e práticas europeus, indicando o êxito do projeto reducional (uma tácita aceitação de que as epidemias "son instrumentos de la divina justicia")?

- Pode ser tomado como uma referência indicativa da negação absoluta do indígena ao seu modo de ser, por assimilação ao OUTRO, através da modelação espiritual prevista no projeto reducional recém-implantado (1609)?

- A referência ao comportamento dos indígenas que "se deixam morrer", pode ser entendida como um julgamento depreciativo e desfavorável, na medida em que eles são tomados por bárbaros, incultos, desprovidos de conhecimentos de medicina e, sobretudo, de iniciativa (considerando-se a valorização desse comportamento na sociedade ocidental)?

- Ou a referência deve ser tomada como manifestação de uma resistência velada/passiva ao projeto reducional (civilizacional e espiritual)?

Esta última indagação, se tomada como afirmação, explicaria o fato de os indígenas não empregarem seus recursos de medicina no tratamento de enfermidades, como nos registros que resgatamos e que se referem a enfermidades de missionários, vistos como pais e protetores dos indígenas reduzidos:

i a los tres dias me vi tan afligido de las llagas de los pies, no pudiendo dar paso mas adelante, los buenos Indios me llevaron otros tres dias en una hamaca. ${ }^{88}$

mas con las oraziones, las oraziones del Pe. que con otro remedio, que no le avia, $\mathrm{ni}$ regalo ninguno... ${ }^{89}$

Também são expressivos os relatos de curas milagrosas através de práticas mágicas, registrados nas Ânuas, como o que se refere à cura de uma mulher acometida de lepra:

Una India de pies a cabeza cubierta de lepra despues de baptizarla con la salud del alma se sirvió nro señor comunicarle tambien la del cuerpo - tienen estos indios particular devocion al agua bendita por las mercedes que nro señor 
por su medio les hace algunos que an padecido mal de ojos con solo lavarse con esta agua quedaban sanos. ${ }^{90}$

Em relação a essas curas, é pertinente, no entanto, observar que "o controle proporcionado por tais ritos mágicos é necessariamente ilusório", 91 pois os amuletos, os encantamentos e a água benta "não possuem qualquer virtude sobrenatural intrínseca". ${ }^{22}$ Apesar de "a magia em si ser vã, ela tem, no entanto, preciosos efeitos colaterais", ${ }^{93}$ diminuindo a ansiedade e predispondo o doente à cura pela imaginação e pela fé.

Este aspecto fica evidenciado na análise que fizemos das Cartas Ânuas da Província Jesuítica do Paraguai, no período que se estende de 1610 a 1643 , e que apontam para o emprego de terapêutica mágica, através do uso de relíquias, do batismo, da extrema-unção, do viático, do licor de São Nicolau, das imagens de santos e da água benta. Empregada em doenças que abrangem desde picadas de cobras, dores musculares, disenteria, inchaço nos olhos, gripe e garganta inchada, peito inchado e febres, até reumatismo, surdez, hemorragias, coqueluche, lepra, varíola, sarampo e câncer, essa terapêutica está associada, invariavelmente, à cura ou à não-cura, ambas manipuladas pelos missionários com a intenção de converter os indígenas, acenando-lhes com a promessa da vida eterna.

Em sua obra Os reis taumaturgos, Marc Bloch (1924) lembrava que os ritos de cura não podem ser pensados e considerados fora das superstições que formam o "maravilhoso" de uma época e das "tendências gerais da consciência coletiva”. As curas realizadas pelos missionários jesuítas nas reduções da Província do Paraguai devem ser analisadas a partir dessa perspectiva, acrescentando-se algumas indagações: os missionários realmente curavam? Se não curavam, como mantiveram a crença em seus poderes? Há que considerar que os missionários referiram essencialmente os casos de doentes que se disseram (e se mostraram) curados após a intercessão dos santos, da água benta, do batismo ou das relíquias sagradas. Não há nenhuma referência aos insucessos nas tentativas de curas, nem menção a recidivas de doenças, o que atestaria que a terapêutica empregada não havia sido eficaz, levando o indígena a repeti-la, ou então, a desacreditá-la. Quando as doenças cediam ou pareciam ceder, dando a "ilusão da cura", estabelecia-se uma relação entre fé e milagre, entre pecado e perdão, entre conversão e cura.

O padrão da transformação das concepções relacionadas à morte e aos mortos, em decorrência do processo de conversão dos Guarani ao Cristianismo, pode, também, ser observado nos relatos referentes a aparições de almas 
do Purgatório e a ressurreições temporárias dos mortos, bem como a aparições de santos e demônios.

Mais do que registrar essas aparições, sonhos e mortes aparentes, as Cartas Ânuas nos permitem avaliar seu impacto sobre as condutas dos índios reduzidos, registrado pelos missionários que não descuidavam de valorizá-los como relatos edificantes. Em relação a muitos desses registros — de cura de indígenas dados como mortos - deve-se considerar a tendência natural do corpo humano de se livrar de algumas doenças sem auxílio externo. Muitos dos achaques curados milagrosamente pertenciam àquela espécie que só o tempo podia curar, tais como as febres e as feridas abertas. ${ }^{94}$ Deve-se, ainda, considerar que as potencialidades dos medicamentos disponíveis eram muito restritas e que muitas das doenças e das curas estavam associadas à fantasia e à imaginação. ${ }^{95}$

Os depoimentos dados pelos índios "ressuscitados" ressaltam as advertências feitas em tom de conselho aos que resistiam ao modo de viver cristão. Essas advertências acabavam por determinar comportamentos defendidos pelos missionários, resultando fundamentais para o êxito do trabalho de conversão.

que, yo no vengo a otra cosa mas que avisar a mis parientes, para que crean lo que vosotros predicais y enseñais de la otra vida, y para que se sepan confesar. ${ }^{96}$

y la agradan mucho los que viven en ella, y os dice la llevéis adelante, $y$ yo de mi parte os lo ruego, y que miréis bien la obligación que tenéis de seguir la virtud, y dar buen ejemplo, $y$ de amar unos a otros, $y$ de cumplir los consejos que os dan los Padres.

Ao relatar um episódio de ressurreição, o Pe. Montoya faz um comentário que confirma o aproveitamento da mística das aparições na modelação espiritual dos Guarani: "los efectos que dejó fueron maravillosos, porque no quedó persona en el pueblo que no se confesase, con muy buenos deseos de imitarla...." 98

Retomando as indagações propostas e a possível interpretação para o fato de os indígenas "se deixarem morrer", perguntamos: o "deixar-se morrer" poderia constituir-se na apropriação — por imitação — de um procedimento religioso-ritual do colonizador, mediante o qual o indígena obteria a "chave de uma libertação" que lhe facultaria "a aquisição de um estatuto idêntico ao do conquistador"? ${ }^{99}$

Em relação a essa interpretação, é preciso considerar que a referência a “deixar-se morrer" integra a Carta Ânua de 1616, e descreve a reação dos indígenas às epidemias e aos seus efeitos devastadores em termos demográficos. É fundamental reconhecer, também, que a passividade registrada pelos missioná- 
rios valorizava a sua atuação, pelo alívio físico e espiritual que proporcionava aos indígenas. A preocupação com o "bien morir", com a salvação das almas dos indígenas, está, com certeza, associada à concepção de "cura" dos missionários, na medida em que se percebiam também como "médicos de almas".

Na medida em que a Igreja pós-tridentina (e os missionários, enquanto seus representantes) valorizava os aspectos exteriores da fé e da devoção, obrigando os indígenas à adesão e à recitação das estruturas formais, a imitação da atitude de resignação pode estar associada ao "deixar-se morrer" enquanto "aquisição de um estatuto idêntico ao do conquistador".

Destacamos uma passagem da Ânua de 1637-1739 que ilustra os aspectos mencionados:

Hallaron un día los Padres a un indio muy anciano en un rancho pajizo. Estaba cubierto de terribles y dolorosas llagas. Con todo estaba muy alegre y contento. Al manifestarle los Padres su comiseración, contestó, muy sério: ¿ Qué es lo que dicen Ustedes, Padres? ¿ Os impresionan mis sufrimientos? Más bien debéis felicitarme por que Nuestro Señor haya hecho tantos favores a un pobre hombre como yo. Estas llagas me parecen regalos. Tengo sólo una pena, y es que estoy imposibilitado de asistir a la Santa Misa... ${ }^{100}$

A possível resignação implícita nessa referência seria resultante da aceitação da "divina justicia" através da adoção do comportamento cristão diante da morte, que implicava percebê-lo como garantia da salvação e da vida eterna, elementos presentes nos sermões dos missionários. ${ }^{101}$

Decorridos mais de trinta anos, esse comportamento pautado pela resignação de uma indígena enferma será novamente registrado pelo Pe. Cristóbal Gomez: "Ella [una indígena congregante] renunció a tomar esta medicina, con permiso de su confesor, porque tuvo escrúpulo en desconfiar a su gran protector San Javier, de que le devolviese la salud". ${ }^{102}$

Outro ponto que sugere maiores reflexões é a utilização de remédios e a operação de curas para a "domesticação" dos indígenas:

por que les buscan las medicinas se las aplican y dan de comer y los sangran por sus manos, y este medio a sido de los que mejor les a salido a los Pes para domesticarlos principalmente a los nuevos. ${ }^{103}$

Os missionários registram os progressos em relação à domesticação-civilização dos indígenas, ressaltando que a conversão humanizava "leones que 
espiraban llamas de furor y vengança”, pacificando-os, através do batismo e das uniões familiares regulares.

Dando continuidade às reflexões, perguntamos: os índios realmente “abraçaram” a religião cristã, sem colocar na conversão motivação de ordem prática - a sobrevivência, por exemplo?

Cabe lembrar, aqui, os registros feitos pelos missionários sobre as insistentes solicitações de batismo pelos indígenas para que não morressem infiéis. No discurso dos missionários essa demonstração de prontidão para a conversão era voluntária e decorria do temor em relação ao inferno e à não salvação da alma.

Na passagem a seguir, extraída da Décima Carta Ânua do Pe. Provincial Pedro de Oñate, referente ao ano de 1617, percebe-se a relação que os missionários estabeleceram entre conversão e proteção divina e a forma que encontraram para "materializá-la" e difundi-la entre os indígenas:

Los otros dias dando una enfermedad, de S. Ignacio se hizo una procesion muy solemne llevando de un pueblo a otro la ymagen con que el Sor servido no pasase adelante la peste ... estan muy adelante en las cosas de Dios, no ay borracheras ni amancebamtos... ${ }^{104}$

As descrições a seguir sugerem que os missionários tinham consciência da vinculação que os indígenas, temerosos em relação à proximidade ou aos efeitos das pestes, estabeleciam entre os sacramentos (confissão e batismo) e a cura ou a salvação e a vida eterna, o que, dada a sua eficácia mecânica, incorria numa visão mágica desses ritos:

y acontecía en tiempo de peste andar rodeando el pueblo todo el día fatigado y despues sin dexarle tomar sueno continuar la noche el trabajo, y su maior recreación era que quando entrava por la puerta de una confesión le estuviesen ya esperando para otra, con esto dezia cobraba aliento... ${ }^{105}$

Cabe observar a percepção realista dos missionários quanto aos condicionantes da conversão, como se percebe neste trecho da Carta Ânua de 1611:

que por la grande falta de agua que ha auido generalmente en toda esta tierra los frutos no se saçonaron, y assi la reducción ha huido entera por la falta de comidas ... por que no teniendola son obligados a andar todo el año tras la caça y assi no pueden ser chatequizados. ${ }^{106}$ 
$\mathrm{Ou}$, ainda, quando admitem que "o fruto do Evangelho depende em grande parte do bom estado da agricultura":

Viendo el Padre cura de este pueblo cómo una casa tras la otra quedaba vacía, averiguó la causa de todo esto, preguntando a varios de los fugitivos. Pero estos no le contestaron más que iban vagando por los montes y campos, porque se había perdido la cosecha pasada, y estaban buscando algo que comer...

Entonces se empeñó en ganarse la confianza de la gente, repartiendo profusamente aquellos donecillos apreciados por los indios, como son los alfilleres, agujas, anzuelos y juguetes. Atraídos por esta liberalidad, volvieron en tropel los fugitivos al pueblo, para recibir también algo de estas cosas buenas....

Comprendió el buen Padre el apuro en que estaba esta pobre gente, y sabiendo de experiencia, que el fruto del Evangelio en gran parte depende del buen estado de la agricultura, mandó que le trajesen todas las heramientas rotas... ${ }^{107}$

Diante dessas informações, cabem as indagações: os índios terão tido consciência de que a estrutura reducional modificou seus hábitos e sua rotina, provocando as condições favoráveis às epidemias? Deve-se considerar que nas reduções havia estoques de alimentos que atraíam ratos, responsáveis, em grande medida, pela disseminação de doenças. Além disso, o confinamento nas reduções e a conseqüente eliminação da prática do nomadismo os tornava mais sujeitos aos ataques dos bandeirantes e ao contágio.

Qual diferença pode ser apontada entre a prática mágica de cura adotada pelos missionários (água benta, pedra de São Paulo, licor de São Nicolau, relíquias sagradas, procissões, intercessões divinas) e a combatida prática de cura dos Guarani?

Qual seria a causa para a negação da validade da medicina guarani a ponto de anulá-la, para então substituí-la por uma outra prática mágica apenas "mais sofisticada"?

As constantes referências à débil medicina e aos poucos recursos dos missionários para conter as epidemias estariam sendo usadas como uma justificativa perante os responsáveis, a Companhia e o Provincial? Diante dessa debilidade e dessa escassez, por que não recorrer à medicina indígena, com as possíveis implicações dessa escolha?

Em relação a essas indagações, consideramos oportuna a transcrição de trecho de uma carta Ânua referente ao período 1663-1666 (decorridos já mais de cinqüenta anos da implantação das reduções) e que nos permite pergun- 
tar: em que difere a prática de cura por sucção, adotada pelo xamã guarani, da empregada pelo missionário?

Un indio sufría una enfermedad muy asquerosa, resistiendo sus apostemas a toda curación. Nuestro Padre, empero, quiso vencer la repugnancia y sanar al enfermo, y por eso pensaba que lo mejor sería besar las llagas, como si fuesen rosas fragrantes, y chuparle materia infecta; lo cual denmuestra que dominaba ya su naturaleza por una larga costumbre. Parece que todo esto aprendió de San Javier, de quien era muy devoto, y a quien procuraba imitar en todo. ${ }^{108}$

É possível ainda adotar uma postura crítica em relação à sinceridade de intenções nos pedidos de batismo (cuja incidência maior se verifica entre velhos e doentes). Nesse ponto, observemos esta passagem, extraída da Carta Ânua de 1615:

Otro de edad ia decrepita se fue de los montes para los Pes. i pidio les con grande instancia le hiciesen luego cristiano, comenzaron a disponerle, i aunque estaba algo enfermo le dilataba el bautismo, porque no mostraba tener riesgo. ${ }^{109}$

Cabe observar, entretanto, que a resistência dos velhos é recorrente nas Ânuas, e, mesmo decorridos já mais de vinte anos da implantação das reduções, os missionários registram:

Costaron particular trabajo las de los viejos que es gente por su rudeza y desamparo mucho mas necesitada y se sierran obstinadamente en que no tienen pecados como los moços y que assi no han menester confesarse, mas todos los que encontraron quedaron remediados y una al parecer de cien años que en toda la vida la aviam podido convencer agora se rindió a la perseverancia de los Padres. ${ }^{110}$

Pode-se, então, perguntar: Qual a "validade” do batismo nesses casos (“in articulo mortis")? É pertinente referir que são freqüentes passagens como a registrada na Carta Ânua referente ao ano de 1614: "Yendo un Pe. a visitar unos enfermos, que estavan en una chacara lexos acaso topo dos, y bautizandolos muy poco despues murieron..." ${ }^{111}$

Que relação poderíamos estabelecer entre a insistência com que os jesuítas indagavam sobre a existência de doentes nas povoações e o êxito da conversão (da domesticação, como refere Nicolas Duran)? É consciente a relação 
doença-cura-conversão por parte dos missionários, tanto quanto para os indígenas é premente a necessidade de sobreviver? Devemos ter presente que os remédios, assim como a oferta de alimentos, são usados como atrativo. Os registros seguintes apontam não só para a constante preocupação com os doentes (e sua potencial cura ou morte), mas também para as dificuldades encontradas pelos missionários em seu propósito de levar ajuda aos enfermos:

demos desto cada dia uno de los Pes, y si es uno solo, el mismo siempre, va recoriendo todas las casas del pueblo para inquirir si ay alguno enfermo... ${ }^{112}$

Hemos hecho algunas salidas por el Rio arriba para ver si podiamos aiudar algunos enfermos, con mucho trabajo, caminando de noche por montes arroyos i malos pasos... ${ }^{113}$

Fundamental, para dar continuidade a esta reflexão, é o resgate de uma passagem em que os missionários referem que após reconhecerem que a peste "había sido enviada de la mano de Dios" "todos se esmeraron en prepararse a bien morir". ${ }^{114}$

Consideramos importante definir qual percepção de "bien morir" vigorava nas reduções jesuítico-guaranis, valendo-nos de passagens das Cartas Ânuas que registram, não só as novas atitudes diante da morte, como também a reformulação dos rituais que a cercam.

La misericordia de Dios es muy grande con estos pobres; mayor todavía con algunos moribundos, los cuales ya medio muertos han alcanzado la saludable medicina (del bautismo) ... Un cacique de noventa años había sido sacado ya por los suyos fuera del pueblo estando el moribundo, para que allí afuera le sepultasen a su manera antigua en un gran cántaro de barro. Lo hice traer, reprendiendo tan grande mal; fué instruído en el catyecismo y sin más dificultad lo pude batizar ... Despues de habérsele proporsionado tan grande benefício, junto él las manos, miró hacia el cielo, me abrazó afectuosamente, como para manifestar su gratitud, y murió tranquilamente. ${ }^{115}$

Assim, é possível dizer que, a partir do novo contexto, o reducional, o "bien morir" para os Guarani implicava ser batizado, ter confessado e ter recebido os sacramentos da Extrema-unção ou Viático. Se o destino da alma causava o temor no homem setecentista, então os sacramentos, que contribuíam para a salvação adquiriam grande importância e o medo de morrer sem eles era avassalador. Só entrava no Purgatório aquele que fosse batizado. 
Na Europa setecentista, a administração dos sacramentos de penitência, eucaristia e extrema-unção visavam ajudar o moribundo a ter uma boa morte. No discurso eclesiástico, o sacramento da comunhão e extrema-unção dado ao moribundo perdoava os pecados pendentes do enfermo, culpas esquecidas durante a confissão. Morrer pecador significava ir para o Inferno, onde a alma sofreria eternos suplícios. Sem dúvida, morrer sem estar em pecado mortal facilitava a ajuda dos santos e do anjo da guarda na salvação da alma. Assim, os últimos sacramentos, incluindo a confissão no leito de morte, perdoavam pecados e salvavam almas. Esta percepção fica evidenciada nesta passagem:

bapticela y despues de poco rato dio el espiritu a su Criador y antes de enterrarla, hice que estubiesse un grande rato assi amortajada como estaba, con la qual se a quitado un grande abuso, y era que apenas habia uno expirado cuando luego le enterraban, ya ha acontecido traherme dos veces un yndio xpño. para que le enterrasen un estando vivo, mas ahora aguardan todo cuanto es necesario. ${ }^{116}$

O que se pode observar nesse registro é a assimilação gradativa do novo ritual funerário, pois a defunta foi amortalhada, tendo sido guardado o tempo necessário (velório) para depois ser enterrada na Igreja, conforme orientação dos missionários que investiram contra o enterro à "antigua usanza". ${ }^{117}$

Con ocasión del alboroto provocado por Miguel se traslado el P. Simón Masetta de Loreto al pueblo de Roque para calmar en algo los animos. Desempeñada ya su tarea, lo registra todo según su costumbre, consuela a los enfermos y ejercita los demas ministérios de la Compañía; cuando de repente advierte que habian enterrado en la Iglesia una difunta, de la cual decían que era todavia pagana. Inmediatamente la hizo desenterrar por el sacristán. Lo supo la madre de la muerta, acudió al Padre, y se quejó amargamente de que sacara del templo a su hija difunta para echarla, así no más, a la basura... ${ }^{118}$

A Ânua referente aos anos de 1641 a 1643 registra a prática do enterro cristão, realçando o ritual solene que o envolvia: "lo pusieron en una caja hecha para este propósito, que llevaron los principales caciques y capitanes; díjosele un responso a canto de órgano, y enterráronlo en el altar mayor, al lado del Evangelio con grande solemnidad..." ${ }_{119}$

Nessa mesma Carta Ânua encontramos referência às missas em intenção das almas dos defuntos, o que revela outro aspecto da assimilação referida: 
"Todo es prueba del gran aprecio que tienen a los sacramentos los de esta reducción; y a las misas tanto que hacen decir muchas por sus padres y madres ya difuntos, $y$ aun aniversarios con la solemnidad que permite su pobreza". ${ }^{120}$

Essas passagens referem o enterro cristão na Igreja e registram a exclusão dos não-batizados desse "privilégio" concedido aos convertidos, portanto, batizados e com conduta irrepreensível. Trata-se aqui de reiterar as condições impostas aos indígenas para poder gozar da bondade divina e de um julgamento favorável na hora da morte.

A Igreja estabelecia uma oposição entre a finitude física e a infinitude da alma e o cemitério era visto como uma espécie de morada dos bem-aventurados, que enfim teriam superado a condição física. Nas reduções havia um muro fechando os cemitérios sobre si mesmos, conferindo-lhes um aspecto de sacralidade, além de reproduzirem a ordem da vida social, uma vez que os túmulos idênticos igualavam os indígenas até na morte. As pompas fúnebres, tais como velórios, missas, responsos e dobre de sinos, também variavam de acordo com a importância do morto. Embora todo defunto tivesse direito a uma missa, as honras eram diferentes. Nos enterros de crianças havia maior aparato, eram acompanhados por outros meninos que, vestidos de branco ou de anjos, carregando flores e círios, cantavam e tocavam em compasso marcado. Eram muito lamentadas as mortes de crianças e como eram também muito freqüentes, acreditava-se em sua transformação em anjos, como afirmavam os padres.

Toda encenação fúnebre, quase festiva, visava a acalmar e consolar a comunidade. O rito fúnebre se constituía em ato social de restauração da ordem, pois conferia sentido à morte através de representações públicas, instituindo uma noção de continuidade em substituição à de fim. O homem cristão deveria acreditar que somente ao morrer iniciaria a verdadeira vida; os ritos fúnebres, o sermão e a missa faziam parte de uma educação para enfrentar a morte, incutindo um determinado ideal de eternidade, relacionado com as maneiras de viver, de se conduzir na vida, incluindo a maneira certa de entender e aceitar a morte.

Como eram muitas as dificuldades, tais como epidemias, ataques, guerras e pragas, gerando doenças, mortes e temor nos índios, era preciso não deixar que tais problemas fossem atribuídos ao descaso de Deus. De modo geral, as adversidades eram definidas como conseqüência das atitudes humanas inadequadas. Ou decorriam da não-intervenção de Deus em favor dos humanos, por seu descontentamento em relação às condutas, ou eram creditadas à 
ação do demônio, que somente se consumava caso as atitudes, condutas e pensamentos humanos fossem propícios à sua presença.

O demônio e as representações do Mal eram tão constantes como as imagens de anjos e santos, pois, para que a existência de Deus fosse ressaltada sistematicamente, também era necessário presentificar a existência do Diabo. As cerimônias rituais rememoravam esse combate entre o bem e o mal e reforçavam a necessidade de manter a vitória do bem.

Tanto quanto Deus, o Diabo era onipresente e estava sempre pronto a intervir com o intuito de se apoderar das almas dos homens. A garantia contra o mal seria a prática constante do bem. E, como a morte era certa, mas não se podia prever quando ocorreria, a idéia de que era preciso estar sempre preparado, em dia com as devoções, permeava todos os fundamentos da conduta religiosa.

A preocupação com a salvação é ressaltada pelos missionários, como num registro referente aos anos de 1641 a 1643, que informa que os indígenas tinham um "cuidado en los principios de su enfermedad" que "era prepararse para cualquier suceso con la confesión, y viatico que pedían luego por ser especie de peste. Y los que de esta o semejantes dolencias se sentían heridos lejos del pueblo al punto se venían a él, y en lugar de pedir les curase los cuerpos, sólo pedían les curasen sus almas...". ${ }^{121}$

Decorridos mais de trinta anos, os missionários jesuítas mencionam a mesma preocupação e o consolo oferecido pela pregação cristã, como observado neste registro que selecionamos e que se refere ao período entre 1672 e 1675. Chamamos a atenção para a descrição do funeral:

Apenas había concluído, cuando llegó un aviso apurado, que había criatura agonizando en los brazos de su madre. Mandó el buen Padre, que se la trajesen, y con permiso de la madre lo bautizó, espirando la criatura luego después, dejando a todos llenos de consuelo por tan felices principios y más a nuestros Padres, por saber ellos que el alma del niño había volado al cielo para acompañar en su felicidad a los miles de miles de bienaventurados. Aumentó todavía más el aprecio de la religión entre los bárbaros, la solemnidad con que la criatura muerta fué conducida a la sepultura en la iglesia por el camino cubierto de flores, y por arcos triunfales hechos de ramas de árboles, en procesión solemne de aquellos distinguidos caballeros, llevada por el mismo señor gobernador, el cual había sido también el padrino de su bautismo, y que había pedido que se pusiese su nombre: Angel. Contemplaban con curiosidad los bárbaros aquellas cerimonias cristianas de la sepultura eclesiástica, porque estos indios proceden muchas veces muy de otro 
modo con sus propias criaturas, en su ciego gentilismo ... Impresionólos [después] en favor de la religión la triste suerte que cupo a los que se habían escapado, a sus antiguas selvas y que fueron condenados a la muerte. ${ }^{122}$

É conveniente observar que os missionários ressaltavam nas Ânuas os efeitos que o temor da morte sem a confissão e sem a absolvição dos pecados e a perene ameaça do inferno produziam sobre os indígenas, levando-os a proceder de acordo com suas recomendações, tanto em razão de medos reais, quanto em decorrência dos "medos construídos". ${ }^{123}$ Isso pode ser observado nestas passagens da Ânua de 1637-1639:

Hubo uno que se adelantó tanto en su temeridad que ni siquiera respetaba el Sacramento de la Confesión. Pero no impunemente había provocado a Dios. Se enfermó gravemente... Sus parientes temían que se les iba a morir y al mismo tiempo que se condenase eternamente, ya que se hizo el desentendido a todos sus caritativos consejos ... Así murió impenitente y fue sepultado en el infierno, para servir de horrible escarmiento a los indios de la reducción ... por justo juicio de Dios fue privado en la hora de la muerte de los consuelos de la religión. ${ }^{124}$

Significativos são também os registros que extraímos da Ânua referente aos anos de 1641 a 1643, que refere que um indígena abraçou "la imagen de Jesucristo para ahuyentarle y que él no quería ir al infierno con el demonio, sino a la gloria con Cristo", ${ }^{125}$ e da Ânua de 1668, em que "la muerte repentina de cierto insigne pecador, ha sido un buen escarmiento para muchos. Pues, murió sin sacerdote, y lo consideraron como un castigo del cielo por las muchas cosas indecorosas que el había hablado en son de burla sobre uno de nuestros Padres". ${ }^{126}$

A necessidade de reafirmar a importância do batismo e da confissão para a absolvição dos pecados transparece também neste registro da Ânua dos anos de 1672-1675, no qual são expostos os objetivos da ação missionária jesuítica e as estratégias empregadas:

De semejante modo les habló el Padre: Que había venido de España a estas remotas tierras, abandonando todo, unicamente para arrancarlos de las tinieblas de la gentilidad y conduzirlos a la admirable luz del Evangelio. Esto sólo era el deseo de su corazón y para lograr este fin, no ahorraría trabajo ninguno hasta que saliesen de la miserable esclavitud del demonio, nuestro cruel enemigo comun. Por lo tanto, que lo escuchasen con docilidad, y que hiciesen todo que les 
iba a enseñar. Entonces, en lugar de marcharse al fuego del infierno, por sus muchos pecados, irían a los premios eternos. ${ }^{127}$

As novas atitudes dos indígenas diante da morte e a disposição em adotar os novos padrões comportamentais e espirituais são realçadas em registros que referem que

Rendíanse a la disposición divina con grande conformidad y paciencia. Acudían los días de fiesta los que podían tenerse en los pies de tres y cuatro leguas cargadas de sus hijuelas por hallarse presentes a la misa y doctrina, disponíanse con grande fervor para la muerte... ${ }^{128}$

A adoção da ritualística cristã e dos padrões morais civilizados garantiram a sobrevivência étnica dos indígenas Guarani face ao avanço das frentes de colonização espanhola e de doenças desconhecidas antes do contato. ${ }^{129}$

Há que se considerar, sem dúvida, que a obediência à nova regra implicava "assimilar tudo que era importante para ser cristão", ${ }_{130}$ o que permitiu que os índios continuassem sendo índios "desde que entrassem na fila e venerassem a presença de Cristo no ostensório que ia à frente". ${ }^{131}$ No entanto, “a ação reconfortante e vivificante" produzida pela cerimônia pública não pode ser minimizada na medida em que reafirmou sentimentos religiosos que "abandonados a si mesmos" teriam arrefecido. ${ }^{132}$ Em razão disso, concordamos com Kern, quando afirma que "foi sempre característica dos Guaranis, a sua religiosidade intensa", ${ }^{133}$ e "a completa convergência ... para os problemas do além". ${ }^{134}$

Feiticeiros (xamãs) e jesuítas vivenciaram, por isso, nas reduções jesuítico-guaranis, "um novo campo de lutas pela manipulação simbólica da condução da vida privada e a orientação da visão de mundo", colocando "em prática na sua ação definições concorrentes, antagônicas, da saúde, do tratamento da cura dos corpos e das almas", já que "os agentes que estão em concorrência no campo de manipulação simbólica têm em comum o fato de exercerem uma ação simbólica". ${ }^{13}$

Somos, por isso, levados a reconhecer a importância do "mistério do ministério", ${ }^{136}$ na expressão de Bourdieu, como razão para que os Guarani passassem a obedecer à nova regra, uma vez que ela interessava ao grupo enquanto garantia dos padrões mínimos da realidade social, bem como de preservação de práticas rituais e do sistema simbólico, apesar de distintos da cultura ancestral. ${ }^{137}$

Sobre essas freqüentes referências às "demostraciones de sentimientos" e 
"chorar copioso", esclarecemos que tanto podiam estar vinculadas à encenação ritual, quanto à consciência da culpabilidade ou à necessidade de demonstração pública de arrependimento, como fica atestado nestes trechos da Ânua de 1632-1634:

Mas el Padre penetrando blandamente sus corazones sus amorosas palabras, les hizo volver en sí, y que se dispusiesen en aquel riguroso trance con mucha penitencia y lágrimas, acavaron todos confesando sus delictos, y deseando muy seguras prendas de la misericordia, que el señor avia usado con sus almas. ${ }^{138}$

Expressões como "bañado en lágrimas", "con lágrimas de dolor y arrepentimiento" e "torrentes de lágrimas" são usadas de forma recorrente na documentação jesuítica referente ao período que analisamos, o que indica a potencialização, pelos missionários, das manifestações dos sentimentos de emoção individual e coletiva dos Guarani.

Y va otra india a oir sermón a una iglesia. Y en el camino le saltó con feas imaginaciones el espiritu de immundicia, y halló en ella entradas por el consentimiento y propósito ... pusose la india delante [retrato de la purisima Virgen] a rezar la salve incadas las rodillas en tierra mas no pudo descubrir con la vista la imagen sagrada ... Desdeñose la madre de pureça de dar oidos a las salutaciones santas que salían de aquel muladar asqueroso, y así los retraxo a los ojos impuros. Caió la triste en la cuenta y muy compungida con este misericordioso desvio derramó de sus ojos muy fervientes lágrimas que arregasen el cierro de sus culpas ... Apenas acabó esta oración quando la madre de pecadores franqueó su rostro venerable, y se dexo ver desta humilde penitente, que luego fue a confesarse... ${ }^{139}$

Os missionários registram também a disciplina e os excessos de devoção religiosa, como nestas passagens que referem a autoflagelação e a apresentam como decorrência natural da nova sensibilidade religiosa, imposta em meio a batismos, visões, confissões, procissões e curas milagrosas: ${ }^{140}$

Sucedió que cierto joven, molestado por la tentación, se echó en un hormiguero. Ya bastante maltratado por esto, se revolvó entre punzantes ortigas. Enfermose por esto, y fué refrenado en sus penitencias por nuestros Padres. Contestó él: No importa. Prefiero morir antes que pecar....

Señales son estas que ya está profundamente arraigado en su corazón el santo temor y amor de Dios. ${ }^{141}$ 
Mais surpreendente, na opinião dos missionários, é o fato de os indígenas manterem "la saludable penitencia", "no obstante la escasez de víveres": "Algunos permanecieron constantes en el pueblo y en las prácticas religiosas, no obstante la escasez de víveres ... Estos indios arrastaron pobremente su vida, extenuados hasta el extremo por un ayuno forzado. Sin embargo no dejaron sus acostumbradas penitencias corporales y sus sangrientas disciplinas". ${ }^{142}$

A prática da penitência, segundo registro extraído da Ânua de 1663-1666, podia ser associada à purificação e às bênçãos divinas que decorriam dela:

La saludable penitencia, que se hace de antemano, previene la satisfacción que nos queda por hacer. Pues, ya estaba la peste asolando los pueblos circunvecinos, y no se atrevió a atacar precisamente este pueblo, defendido por la penitencia, y se detuvo como espantada de su vista. La tierra, empero, humedecida por la sangre derramada por los azotes, que a su vez surcaban los cuerpos, comenzó a producir una riquísima cosecha, mucho más grande que la de las otras reducciones, castigadas por la sequía, así que este pueblo pudo generosamente socorrer a los hambrientos de otra parte. ${ }^{143}$

Há ainda outra vinculação presente no discurso jesuítico, como encontrada na Ânua de 1644, que registra o controle da sexualidade dos indígenas através da identificação das enfermidades venéreas com a punição divina:

Era aquel un buen mozo, pero muy libertino, hasta tal grado que en un solo día había pecado cinco veces; pero al instante le alcanzó la divina venganza, pues, el mismo día enfermó gravemente, estando en un hogar solitario del cual no podía retirarse por falta de fuerzas, por inflamarse sus partes sexuales... ${ }^{144}$

A nova conduta se manifestaria, na "perseverancia en el servicio de Dios", na "firmeza de carácter de los hombres, como en el pudor de las mujeres" e, ainda, no "uso de asperidades corporales para robustecer la fragilidad de la carne". Essa conduta exemplar é constantemente referida pelos missionários que ressaltam o controle das emoções e a adesão a uma nova sensibilidade: ${ }^{145}$

Toda essa multidão se move em tal silêncio que não há pessoa, nem um "muchacho" que fale uma palavra, nem cometa uma ação pouco digna de fazer-se diante do Cristo sacramentado ... iam todos de mãos junto ao peito, os olhos não divagando ao redor, senão modestamente recolhidos, a voz não se ocupava em 
vãs palavras ou em risos senão em cânticos sagrados. De tempo em tempo, incensavam alguns dos acólitos e alternavam com eles outros derramando flores diante do Santíssimo, ou jogando folhas aromáticas de árvores ou grãos de milho tostados que se abriam em forma de flor... ${ }^{146}$

Para os missionários jesuítas, o espírito se encontrava preso dentro do corpo, daí a necessidade de controlar e restringir a ação física, os sentidos, os desejos e vontades, a natureza bruta, a fim de que a alma se desenvolvesse da forma considerada a mais adequada através de espetáculos (que conciliavam a música e as encenações teatrais) e das procissões e das missas em que os indígenas demonstravam sua plena integração na ritualística cristã.

A normatização cotidiana é observável nas referências à existência não apenas de um lugar adequado, mas de um tempo próprio para cada coisa: um dia da semana específico para o batismo, outro para casamentos, dias determinados para confissões e o ponto exato do dia ou da missa em que deveriam ocorrer. A disposição dos fiéis na igreja também era organizada: antes da missa, as crianças separadas em filas por sexo, cantavam no átrio e repetiam orações em voz alta. Depois, entravam na igreja pelas portas principais, as mulheres adultas e, pelas laterais, os homens. A nave central era ocupada pelas autoridades, civis (cabildantes, guerreiros e caciques) que tinham direito a cadeiras e podiam assistir à missa sentados. O resto da comunidade podia sentar no chão ou assistir ao ofício de joelhos. Atrás das autoridades civis ficavam os rapazes e, mais ou menos dois metros atrás, acomodavam-se as moças, evitando-se que houvesse até mesmo um contato visual entre estes. No fundo e nas naves laterais se colocavam as mulheres, e no espaço que sobrava espalhavam-se os homens. Durante toda a missa havia pessoas responsáveis por fiscalizar o comportamento dos índios.

A moderação das emoções pela normatização de ações e a eliminação de comportamentos inconvenientes ficam evidenciadas nas referências à utilização de códigos de postura corporal, tais como os de curvar-se diante do santo em sinal de respeito, baixar a cabeça como forma de aceitar uma ordem, caminhar de uma determinada forma em uma procissão e ocupar um lugar específico dentro da igreja durante a missa, entre outros.

Almas cristãs em corpos dóceis. Não mais corpos voluntariosos, amorais e doentes à espera da salvação de suas almas. Essa é a sensibilidade religiosa que o discurso jesuítico nos revela através das descrições que ressaltam uma profunda comoção e comunhão coletiva dos indígenas nas manifestações de piedade e de devoção reducional. 


\section{NOTAS}

${ }^{1}$ Eliane Cristina Deckmann Fleck é Doutora em História pela PUC/RS, de Porto Alegre, RS, e Professora da Graduação e da Pós-Graduação em História da Unisinos, em São Leopoldo, RS.

${ }^{2}$ HUIZINGA, J. O declínio da Idade Média. Lisboa: Odisséia, 1924, p.102. Segundo Huizinga, "a alma apaixonada e violenta da época, vacilando entre a piedade lacrimosa e a frígida crueldade, entre o respeito e a insolência, entre o desânimo e a licença, não podia dispensar as mais severas regras e o mais estrito formalismo. Todas as emoções exigiam um sistema rígido de formas convencionais, porque sem elas a paixão e a ferocidade causariam a destruição da vida" (p.48.).

${ }^{3}$ THOMAS, K. O Homem e o Mundo Natural. São Paulo: Companhia das Letras, 1988, p.44-6.

${ }^{4}$ BURKE, P. Cultura Popular na Idade Moderna. São Paulo: Companhia das Letras, 1989, p.291-3.

${ }^{5}$ ELIAS, N. O Processo Civilizador. Rio de Janeiro: Jorge Zahar, 1990, p.18.

${ }^{6}$ Ibidem, p.214.

${ }^{7}$ Ibidem, p. 195.

${ }^{8}$ Ibidem, p.91.

9 Barran emprega os termos "bárbara" e "civilizada" para as duas formas uruguaias de sensibilidade do século XIX, caracterizando a primeira como a sensibilidade dos excessos, marcada pela "desorden de los instintos", enquanto a segunda resulta do disciplinamento da sociedade, "de apoderarse de los sentimientos, de las ideas, de los instintos y aun de las impresiones del hombre" que atestam "la fuerza de los sistemas de dominación". Ver BARRAN, J. P. História de la sensibilidad en el Uruguay. Tomo I — La cultura "barbara". Montevideo: Ed. de la Banda Oriental, 1990, p.13, 14, 15 e 227.

${ }^{10}$ Ibidem, p.148.

${ }^{11}$ BURKE, P., op. cit., 1989, p.86.

${ }^{12}$ THOMAS, K. Religião e o declínio da magia. Crenças populares na Inglaterra. Séculos XVI e XVII. São Paulo: Companhia das Letras, 1991, p.19.

${ }^{13}$ Ver THOMAS, K., op. cit., 1991, p.20.

${ }^{14}$ Vale lembrar que além da pregação e da exortação, a confissão constituía, potencialmente, "um sistema de disciplina pessoal" (Ver THOMAS, K., op. cit., 1991, p.140). Para refletir sobre o papel exercido pela Igreja, através da confissão e da penitência, na eliminação 
das condutas-pecado, cabe lembrar uma consideração de Jean Delumeau e que ressalta o caráter de coação existente na confissão obrigatória: "Fazer confessar o pecado para que ele receba do padre o perdão divino e saia confortado: tal foi a ambição da Igreja Católica ... sobretudo a partir do momento em que tornou obrigatória a confissão privada anual e, além disso, exigiu dos fiéis a confissão detalhada de todos os seus pecados 'mortais' ... Era preciso pedir e obter perdão" (DELUMEAU, J. A Confissão e o Perdão. São Paulo: Companhia das Letras, 1991, p.110).

${ }^{15}$ De acordo com Keith Thomas: "Em épocas de calamidade era normal que o clero e o povo invocassem auxílio sobrenatural” (THOMAS, K., op. cit., 1991, p.46); “as comunidades faziam súplicas coletivas, mais caracteristicamente em grandes procissões organizadas pela Igreja” (p.46); "tais procissões eram comuns em relação a peste, más colheitas e mau tempo, na crença confiante de que poderiam levar Deus a mostrar sua misericórdia, desviando o curso da natureza em resposta à contrição da comunidade” (p.47).

${ }^{16}$ Conforme Laplantine, "a doença é vista como a conseqüência do que o próprio indivíduo ou o próprio grupo provocou ... O indivíduo é punido por uma negligência ou por um excesso, mas sempre por um mau comportamento - com relação às prescrições religiosas ... ou seja, por uma falta com relação à ordem social”. (LAPLANTINE, F. Antropologia da Doença. São Paulo: Martins Fontes, 1991, p.228-9). "No Ocidente dos séculos XV-XVII, conheciam-se - e temiam-se — bem umas quarenta doenças designadas pelo nome de um santo, podendo uma mesma enfermidade ser relacionada a vários santos diferentes. As mais temidas, e aparentemente as mais freqüentes, eram o fogo de santo Antônio (ergotismo gangrenoso); o mal de são João, também chamado de mal de saint-Lou (epilepsia); o mal de santo Acário, dito também mal de saint-Mathurin (loucura); o mal de são Roque ou são Sebastião (a peste); o mal de saint-Fiacre (hemorróidas e verruga do ânus); o mal de saint-Maur ou mal de saint-Genou (gota)" (DELUMEAU, J., História do medo no Ocidente (1300 - 1800). São Paulo: Companhia das Letras, 1989, p.71).

${ }^{17}$ MORIN, E. O homem e a morte. Mem-Martins: Publicações Europa-américa, 1988, p.33. Para Elias "el miedo ante la muerte es también, sin duda, un miedo a perder o ver destruido lo que los propios mortales consideran que tiene sentido y llena la vida". (ELIAS, N. La soledad de los moribundos. México: Fondo de Cultura Económica, 1989. p.57).

${ }^{18}$ BASTOS, M. J. da M. Pecado, Castigo e Redenção: a Peste como elemento do proselitismo cristão. (Portugal, séculos XIV-XVI). Tempo, Rio de Janeiro, v.1, n.3, p.184, 1997.

${ }^{19}$ THOMAS, K., op. cit., 1991, p.86.

${ }^{20}$ Ibidem, p.83.

${ }^{21}$ PORTER, R. Corpo e Mente. In: BURKE, P. (Org.) A Escrita da História. Novas Perspectivas. São Paulo: Ed. Unesp, 1992, p.303-4. 
${ }^{22}$ LUZ, M. T. Natural, Racional, Social. Rio de Janeiro: Campus, 1988, p.62.

${ }^{23}$ HUIZINGA, J., op. cit., 1924, p.143.

${ }^{24}$ Referindo-se ao medo excessivo da morte, sentido na Idade Média, Huizinga observa que "as mais cruas concepções da morte, e somente essas se fixavam continuamente nos espíritos ... Mal se descobre a dor pela ausência dos que morrem ... Nem a concepção da morte como consoladora, nem a do repouso há tanto desejado, ou o fim dos sofrimentos, das tarefas cumpridas ou interrompidas têm um quinhão no sentimento funéreo dessa época ... O pensamento dominante ... desse período, quase mais nada conheceu relativamente à morte do que estes dois extremos: a lamentação acerca da brevidade das glórias terrenas e o júbilo pela salvação da alma. Tudo o que entre esses extremos se encontra piedade, resignação, anelo, consolação - ficou sem ser expresso e foi, por assim dizer, absorvido pela muitíssimo acentuada e demasiadamente vívida representação da morte horrenda e ameaçadora" (HUIZINGA, J., op. cit., 1924, p.154-5). Barran observa que "Nos séculos XIV-XVI ... os pregadores falavam da morte para fazerem pensar no Inferno. Os fiéis talvez não pensassem necessariamente no Inferno, mas foram então mais impressionados pelas imagens da morte" (BARRAN, op. cit., 1990, p.149).

${ }^{25}$ BARRAN, J. P., op. cit., 1990, p.169. Edgar Morin observa que "entre todos os paradeiros dos mortos, os mais divulgados são os Infernos, morada subterrânea, ou melhor, reverso da Terra..." (MORIN, op. cit., 1988, p.138). O Purgatório constitui-se em representação eclesiástica do destino das almas dos mortos entre o falecimento e o Juízo Final, surgida a partir do final do século XII.

${ }^{26}$ BASTOS, M. J. da M., op. cit., 1997, p.184.

${ }^{27}$ Ibidem, 1997, p.199.

${ }^{28}$ Ibidem, p.40.

${ }^{29}$ Além das relíquias sagradas, inúmeros talismãs e amuletos eclesiásticos funcionavam "como defesa contra as investidas do Demônio e prevenção contra trovões, raios, incêndios, mortes no parto e perigos similares" (THOMAS, K., op. cit., 1991, p.39).

${ }^{30}$ BASTOS, M. J., op. cit., 1997, p.186.

${ }^{31}$ Keith Thomas ressalta a postura ambivalente da Igreja durante toda a Idade Média: "Assim, os dignitários da Igreja abandonavam a luta contra a superstição sempre que isso lhes parecia de seu interesse ... não tinham a mínima vontade de desestimular atitudes que pudessem aumentar a devoção popular. Se a crença na eficácia mágica da hóstia servia para aumentar o respeito pelo clero e fazer com que os leigos fossem mais regularmente à Igreja, por que então não tolerá-la tacitamente? Práticas como a veneração de relíquias, a recitação de preces ou o uso de talismãs e amuletos podiam chegar a excessos, mas qual o pro- 
blema, enquanto o efeito disso fosse unir mais o povo à verdadeira Igreja e ao verdadeiro Deus? O que contava era a intenção do devoto, e não os meios empregados" (THOMAS, K., op. cit., 1991, p.54).

32 THOMAS, K., op. cit., 1991, p.53 (grifos nossos).

33 "os toques de sinos durante a tormenta, a colocação das cruzes de encruzilhadas para que protejam do granizo os campos vizinhos, o uso de talismãs e 'breves' ... Compreendese, nessas condições, que as populações rurais tenham visto no sacerdote aquele que, dotado pela Igreja de poderes excepcionais, poderia afastar de uma terra granizos e tempestades — manifestações evidentes da cólera divina” (DELUMEAU, J., op. cit., 1989, p.75)

${ }^{34}$ Ibidem, p.53.

${ }^{35}$ DELUMEAU, J., op. cit., 1991, p.110.

${ }^{36}$ Ibidem, p.156-7.

${ }^{37}$ Keith Thomas esclarece: "o fantasma sempre tinha algum motivo particular para reaparecer. Seus movimentos não eram casuais ou sem sentido: acreditava-se invariavelmente que ele tinha alguma meta em vista ... São instrumentos de vingança ou proteção, profetizam ou anseiam ser enterrados decentemente...” THOMAS, K., op. cit., 1991, p.482-3). Ver também DELUMEAU, J., op. cit., 1989, p.86-96.

${ }^{38}$ No século XVII, o Diabo era percebido como "um instrumento do juízo divino, pois os pecadores deste mundo constituíam os membros do reino de Satã após a morte. No Inferno, eles eram submetidos aos imorredouros tormentos que ele presidia. Para ajudá-lo em sua tarefa, ele contava com um exército de demônios e de maus espíritos, tão numerosos e espalhados por toda a parte quanto os santos e anjos de Cristo" (THOMAS, K., op. cit., 1991, p.381).

${ }^{39}$ GARCÍA-ABÁSOLO, A. La vida y la muerte en Indias. Córdoba: Publicaciones del Monte de Piedad y Caja de Ahorras, 1992, p.131.

${ }^{40}$ CERVANTES, F. El Diablo en el Nuevo Mundo. Barcelona: Herder, 1996, p.92.

${ }^{41}$ Ibidem, p.93.

${ }^{42}$ Conforme Cervantes, "El Malleus Maleficarum, por ejemplo, reconocía especificamente que muchas prácticas populares, si bien habían caído en manos de 'gente indiscreta y supersticiosa', tenían un origen completamente sagrado y legítimo, cuando las administraban personas piadosas, ya fueran laicas o religiosas" (CERVANTES, F., op. cit., 1996, p.93).

${ }^{43}$ CERVANTES, F., op. cit., 1996, p.94.

${ }^{44}$ Ibidem, p.53. Ainda conforme Cervantes: "Hacia mediados del siglo XVI, las principales características que contribuirían al surgimiento del tipo de demonismo asociado con la 
caza de brujas llevaban varios siglos de existencia. Ya en el Nuevo Testamento el demonio aparece como la personificación del mal..." (p.34).

${ }^{45}$ CERVANTES, F., op. cit., 1996, p.22.

${ }^{46}$ Ibidem, p.22.

${ }^{47}$ Ibidem, p.68. O autor salienta: "Por consiguiente, las nociones europeas del bien y del mal, personificadas en los conceptos de dios y diablo, suponían un grado de benevolencia y malevolencia completamente extraño a las deidades mesoamericanas. Para el pensamiento mesoamericano, la idea de un dios completamente bueno era un disparate" (p.70).

${ }^{48}$ LOYOLA, I. de. Constituições da Companhia de Jesus. Lisboa: [s.n.], 1975, p.23. Os primeiros jesuítas a lançarem as bases da ação missionária na América chegaram em 1549, acompanhando o primeiro Governador Geral do Brasil, o português Tomé de Souza. E apesar das solicitações feitas, desde 1555, pelos espanhóis estabelecidos no Paraguai, do envio de missionários jesuítas para o serviço espiritual dos colonos e para a conversão dos indígenas já pacificados, somente a partir de 1566 a Companhia de Jesus obteve licença para atuar nos domínios hispânicos. A idéia de fundar missões no Paraguai, entre os Guarani, data de 1552 e foi manifestada pelo Pe. Leonardo Nunes. Esta, no entanto, foi retardada até a aprovação, pelo Conselho das Índias, do envio de missionários jesuítas, ocorrido em 1588.

${ }^{49}$ BANGERT, W. História da Companhia de Jesus. São Paulo: Loyola, 1985, p.20. É importante observar ainda que para Loyola o ideal de santidade tem uma maior significação do que a ciência ou outros dons humanos, o que fica visível na VI Parte das Constituições. (Ver LOYOLA, I. de., op. cit., 1975, p.35).

${ }^{50}$ Como nos lembra Karnal: “Aqui, não se tratava apenas de reforçar o caráter católico, mas também de ensinar os rudimentos do Cristianismo ... Não se tratava de um Cristianismo herético a combater aqui, mas de um Cristianismo a formar. Assim, o zelo da ortodoxia esbarra na América com fenômenos diferentes daqueles dos europeus" (KARNAL, L. Teatro da Fé: Representação religiosa no Brasil e no México no século XVI. São Paulo: Hucitec, 1998, p.61).

${ }^{51}$ Em 1593, ano em que a Província Jesuítica do Paraguai é desmembrada da Província do Peru, chegaram ao Paraguai quatro padres e dois irmãos coadjutores. A extensão da Província e as dificuldades encontradas para o sustento dos missionários forçaram a retirada de todos os padres do Paraguai e de Tucumã, permanecendo apenas um padre em Assunção. O Pe. Diego de Torres Bollo foi enviado à Espanha em 1601, tendo retornado ao Peru, em 1607, na condição de Provincial da nova Província criada pelo Superior Geral. Para discutir as diretrizes básicas da ação a ser adotada pela Companhia na nova Província, Diego de Torres Bollo organizou, no ano seguinte, a 1ª Congregação Provincial. 
${ }^{52}$ MATEOS S. J., F. El Primer Concílio del Rio de la Plata en Asunción (1603). Missionalia Hispânica, Madrid, ano XXVI, n.78, 1969, p.321. É oportuno lembrar: “O jesuíta opõe-se ... a todos os 'vícios' ... Constituem-se como cristãos: castos, sóbrios, tementes a Deus, fidelíssimos aos mandamentos e assíduos aos sacramentos. Assim, o cristão que a Companhia queria produzir era basicamente, um jesuíta" (KARNAL, L., op. cit., 1998, p.67).

${ }^{53}$ A primeira (1609) teve como destinatários os padres José Cataldino e Simão Maceta, enviados ao Guairá, e a segunda (1610) foi destinada a todos os missionários jesuítas atuantes entre os indígenas do Guairá, do Paraná e entre os Guaicuru.

${ }^{54}$ MATEOS, F., op. cit., 1969, p.353 (grifo nosso).

${ }^{55}$ Ibidem, p.348 (grifo nosso).

${ }^{56}$ Ibidem, p.348 (grifo nosso).

${ }^{57}$ Ibidem, p.356 (grifo nosso).

${ }^{58}$ Esse aspecto pode ser observado nesta passagem: “también con los pocos remedios que aca ay procuramos curar los por que ellos no tienen medicinas ni hacen remedios sino dexassen morir" (Novena Carta del Pe. Provincial Pedro de Oñate en que se relaciona lo acaecido durante el año de 1616. In: Documentos para la Historia Argentina. Tomo XX [Iglesia]. Buenos Aires: Talleres Casa Jacobo Preuser, 1929, p.88).

${ }^{59}$ Primeira Instrução do Pe. Diego de Torres Bollo. Apud RABUSKE S. J., A. A Carta-Magna das Reduções do Paraguai. Estudos Leopoldenses, São Leopoldo, v.14, ano XIII, n.47, 1978, p. 25 .

${ }^{60}$ Apud RABUSKE S. J., A., op. cit., 1978, p.23 (grifos nossos).

${ }^{61}$ Conforme L. Karnal, “as relíquias de mártires são tão importantes que acabaram transformando-se em norma canônica: os altares deviam possuir, na sua pedra de ara, uma relíquia de santo mártir ou confessor” (KARNAL, L., op. cit., 1998, p.157).

${ }^{62}$ Ibidem, p.23 (grifos nossos).

${ }^{63}$ Apud RABUSKE S. J., A., op. cit., 1978 (grifos nossos).

${ }^{64}$ LEONHARDT S. J., C. Los Jesuítas y la medicina en el Rio de la Plata. Estudios 57, Buenos Aires, 1937, p.101. E “el Derecho Canónico ... refleja la legislación de siglos al ordenar que 'los clérigos han de evitar, no sólo lo que es indecoroso, sino también lo que es ajeno a su estado. Sin indulto apostólico no deben ejercer la medicina ni la cirurgía ... Dice el canon 985: 'Son irregulares por delito los clérigos que ejercen la medicina o la cirurgía a ellos prohibida, si ejerciéndola causan la muerte" (p.102).

${ }^{65}$ LEONHARDT, op. cit., 1937, p.103. 
${ }^{66}$ GREGORII XIII. Facultas medendi citra adustionem et incisionem, pro medicinae peritis... Apud LEONHARDT, op. cit., 1937, p.104 (grifos nossos).

${ }^{67}$ LEONHARDT, op. cit., 1937, p.110.

${ }^{68}$ Apud RABUSKE, op. cit., 1978, p.24 (grifos nossos).

${ }^{69}$ Ibidem, p.25 (grifos nossos).

${ }^{70}$ Ibidem, p.26 (grifos nossos).

${ }^{71}$ Apud RABUSKE, op. cit., 1978, p.32 (grifos nossos).

${ }^{72}$ Ibidem, p.33 (grifos nossos).

${ }^{73}$ Ibidem, p.33 (grifos nossos).

${ }^{74}$ Ibidem, p.33 (grifos nossos).

${ }^{75}$ Ibidem, p.34 (grifos nossos).

${ }^{76}$ ELIADE, M. O Sagrado e o Profano. A essência das religiões. Lisboa: Livros do Brasil, [s.d.], p.192-3.

${ }^{77}$ Carta Ânua do Pe. Antonio Ruiz, Superior da Missão do Guairá, Dirigida em 1628 ao Pe. Nicolau Duran, Provincial da Companhia de Jesus. In: Manuscritos da Coleção De Angelis (MCA). v.I (Jesuítas e Bandeirantes no Guairá (1549-1640). Introdução e notas por Jaime Cortesão. Rio de Janeiro: Biblioteca Nacional, 1951, p.274.

${ }^{78}$ MONTOYA, A. R. de. Conquista Espiritual. Porto Alegre: Martins, 1985, p.54-5.

${ }^{79}$ Suplemento del Anua Pasada del Año 1614 de la Misión de Guayra. In: Documentos para la Historia Argentina. Tomo XX. (Iglesia), 1929 (grifo nosso).

${ }^{80}$ Décima Cuarta Anua en donde se relaciona lo acaecido en los años 1635-1637. In: Documentos para la Historia Argentina. Tomo XX. (Iglesia). Buenos Aires, 1924, p.702 (grifo nosso).

${ }^{81}$ Para os Guarani, não havia ligação entre o livre-arbítrio e o post-mortem, "pois não há castigo após a morte, nem condenação eterna. As únicas dificuldades para o acesso à Terra sem Mal são os acidentes de percurso que a alma tem que percorrer. Isso implica também uma ausência de pavor ou desespero ante a morte e a não tolerância de qualquer tipo de cerceamento à sua liberdade ... A doutrina cristã, ao contrário da indígena, não pode ser concebida sem a noção de que no além a alma será julgada pelos seus atos e condenada ou recompensada, em virtude de seus atos aqui na terra" (KERN, A. Missões: uma utopia política. Porto Alegre: Mercado Aberto, 1982, p.102-3).

82 "A paixão momentânea e os impulsos afetivos são, por assim dizer, reprimidos e dominados pela previsão de aborrecimentos posteriores, pelo medo de uma dor futura, até que 
pela força do hábito, esse medo finalmente contenha o comportamento e as inclinações proibidas ... e a energia dessas inclinações seja canalizada numa direção inócua, sem o risco de qualquer aborrecimento" (ELIAS, N., op. cit., 1990, p.227).

${ }^{83}$ ELIAS, N., op. cit., 1990, p.268-9. Em sua análise, Elias reforça que "Os medos formam um dos canais - e dos mais importantes - através dos quais a estrutura da sociedade é transmitida às funções psicológicas individuais ... a possibilidade de sentir medo, exatamente como a de sentir alegria, constitui parte inalterável da natureza humana ... A vergonha, o medo da guerra e o medo de Deus, o medo que o homem sente de si mesmo, de ser dominado pelos seus próprios impulsos afetivos, todos eles são direta ou indiretamente induzidos nele por outras pessoas" (p.269-70).

${ }^{84}$ SWAIN, T. N. A construção imaginária da história e dos gêneros: o Brasil no século XVI. Textos de História. Brasília, Revista do Programa de Pós-Graduação em História da UnB, v.4, n.2, 1996, p.133.

${ }^{85}$ Resgato aqui as considerações de Tânia Navarro Swain sobre a ação do maravilhoso (sobrenatural) e do real (natural) sobre as representações, ao afirmar que "os cronistas hesitam entre o maravilhoso e a terra firme de suas representações. O maravilhoso aparece apenas para melhor desaparecer, para melhor assegurar o ordenamento do mundo, seus valores e suas imposições" (SWAIN, op. cit., 1996, p.145). Nessas descrições o maravilhoso foi suplantado pelo real.

${ }^{86}$ MAEDER, E. J. A. (Org.) Cartas Ânuas de la Provincia del Paraguay (1637-1639). Buenos Aires: FECIC, 1984, p.88.

${ }^{87}$ Novena Carta del Pe. Provincial Pedro de Onate en la que se relaciona lo acaecido durante el año de 1616. In: Documentos para la Historia Argentina. Tomo XX. (Iglesia), 1929, p.88.

${ }^{88}$ Duodécima Carta del Pe. Nicolás Durán (1626-27). In: Documentos para la Historia Argentina. Tomo XX. (Iglesia), 1929, p.310 (grifos nossos).

${ }^{89}$ Ibidem, p.294 (grifos nossos).

${ }^{90}$ Novena Carta del Pe. Provincial Pedro de Oñate en la que se relaciona lo acaecido durante el año de 1616. (Ref. Mission y reduciones de nra señora de Loreto y Sto Ignacio de Guayra.). In: Documentos para la Historia Argentina. Tomo XX. (Iglesia), 1929, p.98.

${ }^{91}$ THOMAS, K., op. cit., 1991, p.527.

${ }^{92}$ Ibidem, p.181.

${ }^{93}$ Ibidem, p.527.

${ }^{94}$ Vale aqui referir as observações de Jacques Le Goff sobre as curas das escrófulas pelo toque régio tratadas por Marc Bloch em Os Reis Taumaturgos: “Às vezes, as doenças mais ou 
menos confundidas sob o nome de escrófulas ou alporcas curavam-se espontaneamente, se bem que amiúde de forma incompleta ou temporária. A natureza fazia o milagre. Como em geral a cura acontecia bastante tempo depois do cumprimento do rito de cura, as pessoas acreditavam facilmente na realidade de um milagre retardado" (LE GOFF, J. Prefácio. In: BLOCH, M. Os Reis Taumaturgos. São Paulo: Companhia das Letras, 1993, p.27). Pode-se aqui estabelecer uma aproximação entre as curas milagrosas referidas por Bloch e as registradas pelos missionários nas Cartas Ânuas, na medida em que, em alguns casos, a "natureza" promovia a melhora do doente.

${ }^{95}$ Em relação a este ponto, é preciso ressaltar que a medicina de outrora era praticamente incapaz de descobrir e de avaliar as recidivas das doenças. Além disso, os médicos, à época (século XVII), não tinham à sua disposição nem uma terminologia muito rigorosa, nem métodos de diagnóstico muito seguros. Havia, segundo Marc Bloch, algumas doenças capazes de facilmente dar a ilusão de cura, "pois com bastante freqüência suas manifestações ... desaparecem de forma espontânea, ainda que para reaparecer mais tarde" (BLOCH, M., op. cit., 1993, p.277). Numa referência ao que denominou "explicação psicoterápica do milagre régio", Bloch nos lembra que: "No tempo em que os reis da Inglaterra benziam os cramp-rings, decerto se confundiam sob o nome de epilepsia ... muitas outras desordens nervosas ... que tinham origem puramente emocional ou que a neurologia moderna incluiria no grupo de fenômenos nascidos da sugestão ou da auto-sugestão ... todos eles acidentes que um choque psíquico ou a influência sugestiva de um talismã são perfeitamente capazes de fazer desaparecer ... Segundo tudo indica, alguns dos usuários dos anéis deveram sua cura (ou talvez a atenuação de seus males) muito simplesmente à robusta fé que haviam devotado ao amuleto régio" (p.272).

${ }^{96}$ MONTOYA, A. R. de., op. cit., 1985, cap. XVII, p.98.

${ }^{97}$ Ibidem, cap. XL, p.180 (grifo nosso).

${ }^{98}$ Ibidem, p.181.

${ }^{99}$ Ver ENCICLOPÉDIA EINAUDI: RELIGIÃO. Lisboa: Imprensa Nacional-Casa da Moeda, v.30, 1985, p.240.

${ }^{100}$ MAEDER, E. J. A. (Org.), op. cit., 1984, p.35 (grifo nosso).

${ }^{101}$ Como bem salientou Bosi, essa aceitação resulta de uma "fixidez enigmática do destino perante o qual não restaria ao sujeito mais do que curvar-se humildemente" (BOSI, A. Dialética da Colonização. São Paulo: Companhia das Letras, 1992, p.86).

${ }^{102}$ Cartas Ânuas de la Província del Paraguay — de 1669 a 1672. Tradução de Carlos Leonhardt S. J., 1927, p.5 (Mimeogr.).

${ }^{103}$ Duodécima Carta del Pe. Nicolás Mastrillo Duran en la que se relaciona lo acaecido en 
la Provincia en los años 1626 y 1627. In: Documentos para la Historia Argentina. Tomo XX. (Iglesia), 1929, p.266 (grifo nosso).

${ }^{104}$ Duodécima Carta del Pe. Provincial Pedro de Oñate, en la que se relaciona lo acaecido durante el año de 1617. In: Documentos para la Historia Argentina. Tomo XX. (Iglesia), 1929, p.146 (grifo nosso).

${ }^{105}$ Ibidem, p.45 (grifos nossos).

${ }^{106}$ Carta Ânua de 1611, do Pe. Diego de Torres. In: PASTELLS, R. P. S. J. História de la Compañia de Jesus en la Provincia del Paraguay. Tomo I. Madrid: Librería General de Victoriano Suárez, 1912, p.168 (grifo nosso).

${ }^{107}$ Décima Cuarta Carta Anua en donde se relaciona todo lo acaecido en los años 16351637. In: Documentos para la História Argentina. Tomo XX (Iglesia), 1929, p.576 (grifos nossos).

${ }^{108}$ Cartas Ânuas de 1663-1666. Anuas de la Província del Paraguay. Traducción de Carlos Leonhardt, 1928, p.92 (Mimeogr., grifo nosso).

${ }^{109}$ Octava Carta del Pe. Provincial Pedro de Oñate, en la que se relaciona lo acaecido durante el año de 1615. In: Documentos para la Historia Argentina. Tomo XX. (Iglesia), 1929, p.296 (grifo nosso).

${ }^{110}$ MAEDER, E. J. A. (Org.). Cartas Ânuas de la Provincia del Paraguay (1632 - 1634). Buenos Aires: Academia Nacional de Historia, 1990, p.33.

${ }^{111}$ Suplemento de la Octava Carta Ânua, del año de 1614, de la Mission de Guayra. In: Documentos para la Historia Argentina. Tomo XX. (Iglesia), 1929, p.56 (grifo nosso).

${ }^{112}$ Duodécima Carta del Pe. Nicolas Mastrillo Durán (1626-1627). In: Documentos para la Historia Argentina. Tomo XX. (Iglesia), 1929, p.266 (grifo nosso).

${ }^{113}$ Ibidem, p.289.

${ }^{114}$ Décima Cuarta Carta Ânua de la Provincia del Paraguay, Chile y Tucumán, del año de 1634. In: Documentos para la Historia Argentina. Tomo XX. (Iglesia), 1929, p.702.

${ }^{115}$ Duodécima Carta Anua del Pe. Nicolas Mastrillo Durán (1626-1627). In: Documentos para la Historia Argentina. Tomo XX. (Iglesia), 1929, p.346 (grifos nossos).

${ }^{116}$ Anua de la Provincia del Paraguay, Chile y Tucumán, del año de 1611. In: Documentos para la Historia Argentina. Tomo XX. (Iglesia), 1929, p.504 (grifos nossos).

${ }^{117}$ De acordo com Melià, "el entierro, cuando ocurre, se lleva a cabo como última ceremonia del día, al entardecer, lo traen hasta la iglesia, hay rezos y cantos de los músicos, pero también 'desentonados' lamentos de indias viejas — antigua costumbre que muchos años de misión no han podido desarraigar - y en los que lloran y elogian al difunto por lo que 
ha sido y ha hecho o al menos por lo que hubiera podido hacer y hubiera podido ser, de haber seguido viviendo" (MELIÀ, B. El Guaraní - Conquistado y Reducido. Asunción: Centro de Estudios Paraguayos, 1986, p.207.)

${ }^{118}$ Duodécima Carta Anua, del P. Nicolas M. Durán, en la que se relaciona lo acaecido en la Provincia en nos años de 1626 y 1627. In: Documentos para la Historia Argentina. Tomo XX. (Iglesia), 1929, p.332 (grifo nosso).

${ }^{119}$ Cartas Anuas de la Provincia Jesuítica del Paraguay — 1641 a 1643. Documentos de Geohistoria Regional, n.11, Instituto de Investigaciones Geohistóricas. Resistencia, Chaco, 1996, p.120.

${ }^{120}$ Ibidem, p.79 (grifo nosso).

${ }^{121}$ Cartas Anuas de la Provincia Jesuítica del Paraguay — 1641 a 1643. Documentos de Geohistoria Regional, n.11. Instituto de Investigaciones Geohistóricas. Resistencia, Chaco, 1996, p.86.

${ }^{122}$ Cartas Anuas de la Provincia del Paraguay — Años de 1672-1675. Traducción de Carlos Leonhardt S. J. Buenos Aires, 1927, p.34-5 (Mimeogr., grifo nosso).

${ }^{123}$ Vale lembrar a afirmação de Norbert Elias: "Só obtemos uma melhor compreensão das mudanças da conduta e sentimentos numa direção civilizadora, se nos tornarmos conscientes das mudanças na estrutura dos medos construídos, a que eles estão ligados" (ELIAS, N., op. cit., 1989, p.269).

${ }^{124}$ MAEDER, E. J. A. (Org.), op. cit., 1990, p.91 (grifo nosso).

${ }^{125}$ Cartas Anuas de la Provincia Jesuitica del Paraguay - 1641 a 1643. Documentos de Geohistoria Regional, n.11. Instituto de Investigaciones Geohistóricas. Resistencia, Chaco, 1996, p.92.

${ }^{126}$ Cartas Anuas de la Provincia del Paraguay — Año de 1668. Traducción de Carlos Leonhardt S. J. Buenos Aires, 1927, p.20 (Mimeogr., grifo nosso).

${ }^{127}$ Cartas Anuas de la Provincia del Paraguay — años de 1672-1675. Traducción de Carlos Leonhardt S. J. Buenos Aires, 1927, p.34 (Mimeogr., grifo nosso).

${ }^{128}$ Ibidem, p.132, grifo nosso.

${ }^{129}$ Em relação a essa nova ordenação simbólica, Karnal aponta para a dificuldade da transposição e da tradução cultural e lingüística. Os jesuítas, segundo ele, "são os que mais se esforçam na fundação de uma nova ordem, a ordem cristã. Buscam palavras, compõem catecismos, gramáticas, diálogos e fazem peças bilíngües. Trata-se de um esforço integrador, não segregador" (KARNAL, L., op. cit., 1998, p.202.) Janice Theodoro, ao ressaltar a importância da linguagem das formas e da representação cênica para que o indígena com- 
preendesse como se estruturava o pensamento europeu, destaca também a preservação da diversidade lingüística "que permitiu que o indígena percebesse como as palavras e a sintaxe das línguas em que se comunicava compunham as coisas e as suas qualidades. Armados desses conhecimentos, foi possível ao índio americano fazer conexões surpreendentes" (THEODORO, J. América Barroca. Temas e Variações. Rio de Janeiro: Nova Fronteira, São Paulo: Edusp, 1992, p.106). A compreensão do universo simbólico cristão-ocidental tornou possível à "cultura índia manter-se dissimulada” (p.107), na medida em que dominando esse código, os indígenas podiam "conjugar ou miscigenar os acervos culturais" conforme "parecesse mais conveniente, mantendo intactos os seus pressupostos cognitivos" (p.107-8).

${ }^{130}$ KARNAL, L., op. cit., 1998, p.229.

${ }^{131}$ Ibidem, p.168.

${ }^{132}$ DURKHEIM, E. As formas elementares da vida religiosa. São Paulo: Paulinas, 1989, p.264.

${ }^{133}$ KERN, A., op. cit., 1982, p.105.

${ }^{134}$ Ibidem, p. 102.

${ }^{135}$ BOURDIEU, P. Coisas Ditas. São Paulo: Brasiliense, 1990, p.121. Deve-se reconhecer como Bourdieu que "essas pessoas que lutam para dizer como se deve ver o mundo são profissionais de uma forma de ação mágica, que, mediante palavras capazes de falar ao corpo, de 'tocar', fazem com que se veja e se acredite, obtendo desse modo efeitos totalmente reais, ações" (p.121).

${ }^{136}$ BOURDIEU, P., op. cit., 1990, p.167.

${ }^{137}$ Susnik, em artigo sobre a cultura indígena e sua organização social dentro das missões jesuíticas, observa que "música, danzas religiosas y simbólicas, oraciones cantadas, solemnidad de domingos, celebración de fiestas religiosas ... fueron ocasiones propicias para dar a la muchedumbre un desahogo psico-emocional tanto colectivo como individual ... el nuevo patrón emocional se basaba en factores puramente impresivos y audio-visuales, en pleno contraste con la antigua participación vivencial de las danzas sagradas". A antropóloga enfatiza que para os Guarani “estas expresiones no eran mas que una 'faena' agradable a su natural ambición psicomental" (SUSNIK, B. La cultura indígena y su organización social dentro de las misiones jesuíticas. Suplemento Antropológico, v.XIX, n.2, dec.1984, Universidad Católica, Asunción, p.16).

${ }^{138}$ Ibidem, p.71 (grifo nosso).

${ }^{139}$ Ibidem, p.63 (grifo nosso).

${ }^{140}$ Em relação aos meios pelos quais se expressa a sensibilidade religiosa nas reduções, consideramos oportuno destacar algumas passagens dos "Exercícios Espirituais" e que refe- 
rem a salvação como esforço pessoal e a "reforma da vida": "A salvação da minha alma é trabalho meu pessoal, pois não posso confiar a outro ... que todo depende de mim, e é da minha absoluta responsabilidade...” (Apud MONTEIRO S. J., Pe. A. Exercícios de Santo Ignácio de Loyola. Petrópolis: Vozes, 1950, p.27); “é fazermos agora, por nós mesmos, penitência de nossos pecados, e praticar boas obras, o mais que pudermos e, não pôr unicamente a nossa esperança nos sufrágios dos vivos..." (p.96); e "A matéria desta forma pode ser a seguinte: as paixões não inteiramente domadas — os maus hábitos — as inclinações desordenadas..." (p.236).

${ }^{141}$ MAEDER, E. J. A. (Org.), op. cit., 1984, p.129 (grifo nosso).

${ }^{142}$ Ibidem, p.102-3.

${ }^{143}$ Anuas de 1663-66. Anuas de la Provincia del Paraguay. Trad. Carlos Leonhardt. Buenos Aires, 1927, p.103 (Mimeogr., grifos nossos).

${ }^{144}$ Anuas de 1644. Anuas de la Provincia del Paraguay. Trad. Carlos Leonhardt. Buenos Aires, 1927, p.92 (Mimeogr., grifo nosso).

${ }^{145}$ MAEDER, E. J. A. (Org.), op. cit., 1984, p.108. Com relação ao valor atribuído pelo missionário ao pudor demonstrado pelas mulheres, vale lembrar que "o pudor só nasce com a consciência do mal” (BOLOGNE, J. C. História do Pudor. Lisboa: Teorema, 1986. p.376).

${ }^{146}$ CARDIEL, J. De Administrationem guaranítica. Versão espanhola de Juan Cortés de Pino. Buenos Aires, 1946, p.313. 